\title{
هق الإجازة للمرأة العاملة في القطاعين العام والخاص
}

\section{م. اممد حمزة نماصر \\ م.م ستنار جابر عبيد}

الإقدمة

منذ أن خلق الهه سبحانه وتعالى آدم عليه السلام وخلق حواء لتكون سكناً له ومودةً ورحمةً بينهما، و همـا شركاء في العمل في الحياة الدنيا ومتساويان في الأجر والثواب حيث أنهما في الأصل شركاء في الإنسانية أياً كان لونهم أو دينهم أو جنسيتهم إلا أن المرأة مرت عبر العصور المختلفة بمو اقف كانت فيها حقوقها وكر امتها

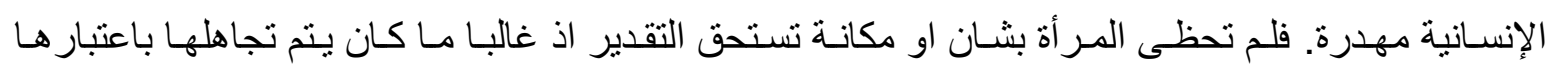
الطرف الضعيف والمشؤوم او في احسن الاحوال كانت تثير العطف والثفقة فهذا التمييز كان يتباين في الثدة

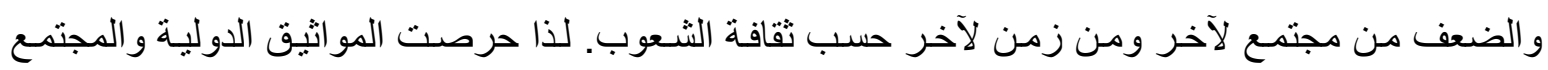

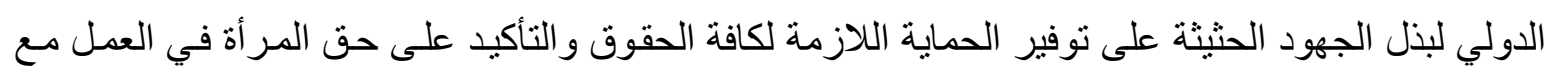
الرجل من خلال اعلانات المو اثيق والمعاهدات الدولية التي تضمنت المسـاو اة في كافة مظـاهر الحياة داخل المجتمع الواحد دون أي تفرقة أو عصبية.

وكذلك التشريعات الداخلية في النظم المقارنة منحت المر أة مكانة خاصة لدور ها وطبيعتها الفسيولوجية ووضـت بعض القيود على عملها وميزتها بمحددات قانونيـة راعت فيها تلك الطبيعهة ومن هذه الميزات خصوصية حق المر أة العاملة في القطاعين العام والخـاص في الاجـازة. فقد منحت التشريعات المر أة عدة انواع من الإجاز ات زخرت احكامها بالمساو اة مع الرجل في ميادين العمل بصفة عامة باعتبار هما موظفين او

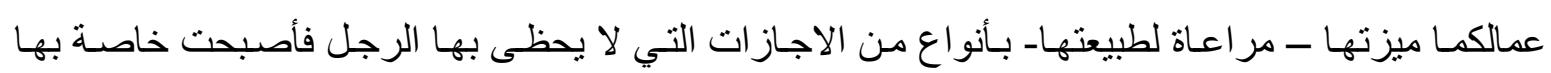
كاجازة الحمل الأمومة والعدة. وتختلف النظم القانونية الخاصة بالاجازة من مشرع لاخر وفي البلا الواحد من تشريع لاخر، سواء في القو انين الخاصـة بالوظيفة العامـة والتي تتـمل الموظفـة العامـة او الخاضـعة لقو انين العمل، وتشـمل العاملـة بالقطاع الخاص الامر الذي يستوجب منـا البحث في هذا الموضوع و البحث في بيـان هذه الانواع من هذه الاجازات حسب القوانين الخاضعة له وتقيميها مع الغرض المرجو منه.

\section{المبمش الأول- الإجازات الطبيعية}

يحتاج الموظف و الموظفة بوصفهما بشراً الى مدة معينة يتتـاول من خلالها قسطا من الراحة ليتجنب الاعياء ، فضلا عن انها ترد على العمل بنتيجـة ايجابيـة وهي تجديد نشـاطهما. كما ان حق الدراسـة مكفول دستوريا للموظف و غيره من فئات المجتمع ، وهو امر يتطلب تدخل المشرع لتنظيمه اذا مـا اراد تكريس هذا الحـق الدستوري للموظف ـلذا سـنتناول في هذا المبحث الاجـازة الاعتياديـة في المطلب الاول و الاجـازة الدراسية في المطلب الثاني. 


\section{المطاب الأول- الإجازة الإدارية أو الاعتيادية}

هي فترة غياب مرخصة تنقطع فيها الموظفة عن عملها للراحة ، كي يتسنى لها بعد انقضـائها العودة الى عملها بنشاط و اندفاع ، وتتقاضى الموظفة راتبها كاملا خلال مدة هذه الاجازة التي تعتبر من عداد الخدمـة

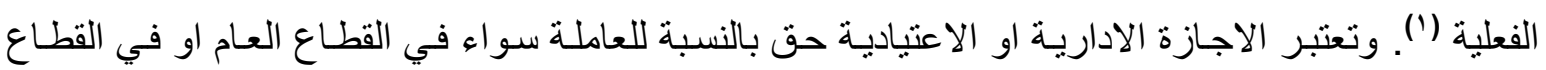
الخاص ، وذلك لتمكينها من استعادة نشـاطها من خلال توفير الراحة لها بعد العمل المتو اصل ، فـالغرض الرئيسي منها زيادة حيويتها ، و استعادة نشـاطها ، وتجديد قواهـا الفكريـة و الجسدية لتعود بعد ذلك اكثر همـة و اقبال لمتابعة عملها، وبالتالي ينعكس ايجابا على الجهاز الاداري التابعة له. وتختلف التشريعات المقارنـة في

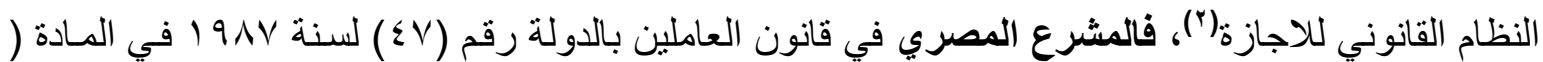
ه 1 ) منه نصت على استحقاق ((العامل اجازة سنوية بـاجر كامل لا يدخل في حسـابها ايام عطلات الاعياد و المناسبات الرسمية فيما عدا العطلات الاسبو عية وذلك على الوجه التالي:-

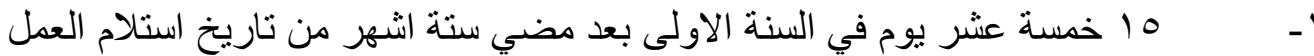

$$
\text { ع }
$$

وللجنة شؤون الخدمة المدنية ان تقرر زيادة مدة الاجازة الاعتيادية بما لا يتجاوز خمسة عشر يوم لمن يعملون في المناطق النائية او اذا كان العمل في احد فروع الوحدة خارج الجمهورية )). اما بالنسبة للمشرع اللبناني فقد نص على استحقاق الموظفة بعد انقضـاء سنة على تعينها ، وفي كل سنة لاحقة تقتضيها في الخدمة الفعلية اجازة سنوية براتب كامل لمدة عشرون يوم(").

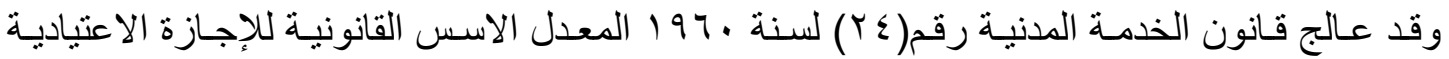
بصورة مختلفة من خـلال نص المـادة (rع) و التي نصت على (بستحق الموظف اجـازة اعتياديـة بر اتب تام بمعدل يوم واحد عن كل عشرة ايام من مدة خدمته ) .

يلاحظ على ما سبق بان هنالك تمايز في موقف التشريعات في معالجتها لموضوع الاجازة ، فالمشرع المصري قد ربط رصيد الاجـازة بمدة الخدمة والعمر ، امـا بالنسبة لموقف المشرع اللبنـاني فلم يفرق بهذا الخصوص الا انه استتنى من ذلك الموظفة تحت التجربـة ، كذلك ايضـا ان المشرع العراقي لم يفرق بين موظفة واخرى على اساس الاقدمية والعمر ـ ونرى ان موقف المشرع المصري فيمـا يتعلق بربط الاجـازة على اساس الخدمة والعمر الاكثر تو افقا نظر الما قدمته من خدمة في الحالة الاولى ،كما ان زيادة مدة الاجازة بسبب كبر السن له ضرورة في اداء عملها من خلال اعادة نشاطها في الحالة الثانيـة يلاحظ ايضـا ان المشرع العر اقي ساوى بين الموظفة تحت التجربة و الموظفة المثبتة كما في الفقرة الخامسة من المادة (rع ) من قانون الخدمة النافذ وهذا الاتجاه من قبل المشرع محمودا عليه . 
اما فيمـا يتعلق بالموظفة التي تكون خاضعة لقانون الخدمة والتقاعد لقوى الامن الداخلي رقم( ^) (

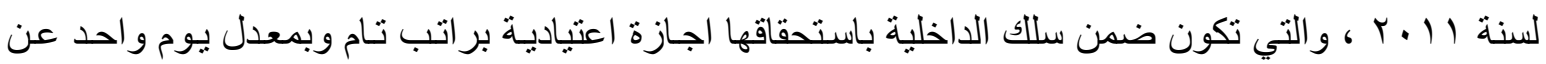
كل عشرة ايام من مدة الخدمة (؛).

كذلك ان المشرع العراقي قد استثنى بعض الفئـات الخاضعة لقانون الخدمـة المدنيـة النافذ مـن المدة المذكورة سابقا ، و هم المشمولين بالعطلات المدرسية كالمعلمات والمدرسات ، فتكون مدة اجازتهم سبعة ايام

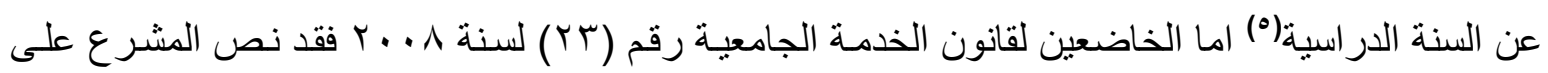
حق الموظفة بإجازة بمدة لا تزيد على خمسـة عشر يوم في السنة ،ويجوز تر اكم هذا الاجـاز ات على ان لا

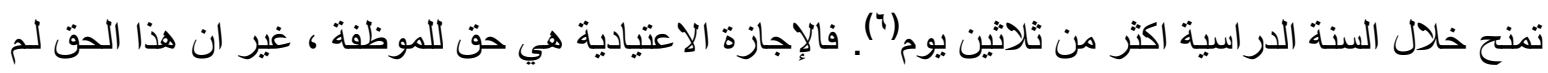

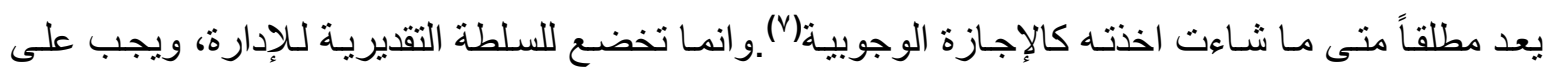
الموظفة ان تتقيد بعدة امور، وتر اعي الاجر اءات المتبعة في ذلك ، منها ان تكون عن طريق تقديم طلب

تحريري الى الرئيس الاداري الذي يكون له الحق بالرفض او المو افقة مالم تضر المصلحة العامة(^). اما في حال تقديم طلب الاجـازة بمضـي مدة ستة اشـهر فلا يحق للرئيس الاداري الامتتـاع عن منح

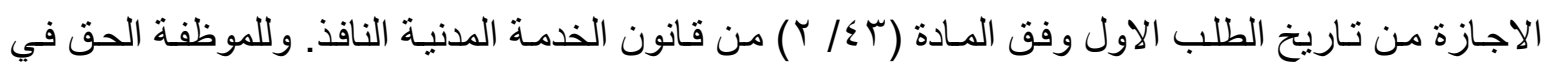
طلب الاجـازة في ابي وقت حسب رغبتها ومدى حاجتهـا للاجـازة ،كمـا يحـق لهـا الاحتفـاظ برصبدها مـن

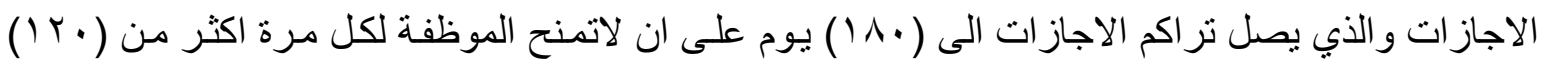
يوم ، وتكون براتب تام مع تدوير باقي الاجاز ات لرصيد الموظفة(ج). وتمنح الموظفة المنتهية خدمنها المحالة الى التقاعد في غير حالتي العزل والفصل الرواتب الاسمية

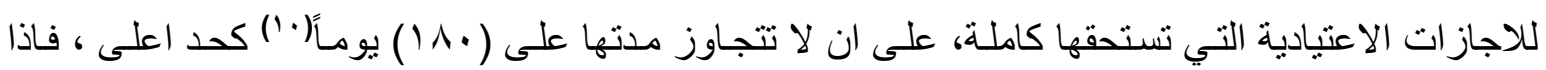

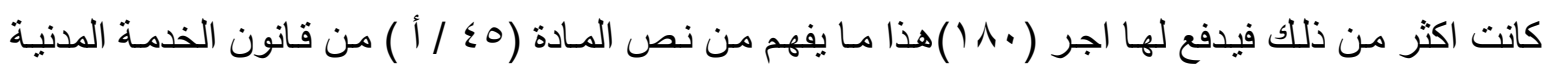

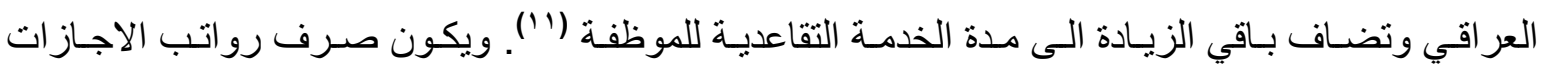
الاعتيادية المتر اكمة للموظفة المحالة الى التقاعد على اساس آخر راتب تقاضته عند احالتها الى التقاعد (r'). ويسري هذا المبدأ على الموظفة المتمتعـة بالعطلـة الصيفية، وهذا مـا كرسـه مجلس الانضباط العـام

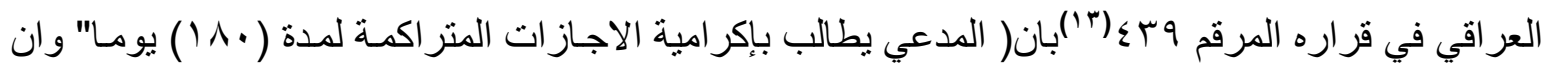
المدعى عليهما رفضا منحه ذلك بادعاء ان التدريسيين والهيئات التعليمية لا يستحقون لعدم وجود متر اكم من بن بله الاجـاز ات لكونهم يتمتعون بـالعطلات المدرسية ويمنحسون اجـازة لمدة (V) ايسام وان الفقرة (Y) مـن المسادة

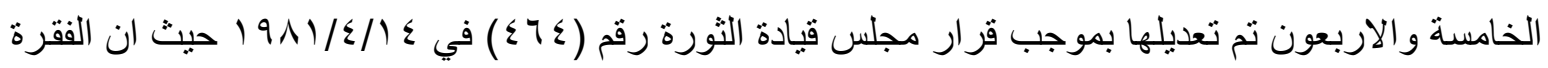

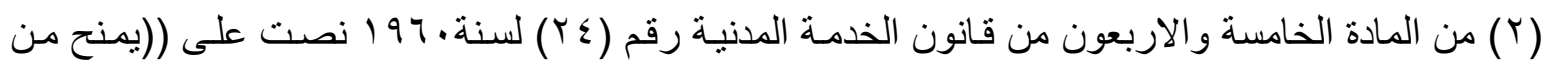
يتمتع بالعطلات المدرسية اذا انتهت خدمته بتنسيق المـلاك او بالإحالة على التقاعد في غير حالتي العزل او الفصل في النصف الثناني من السنة الدر اسية او خـلال العطلة الصيفية رواتب العطلة الصيفية على ان لا لانل

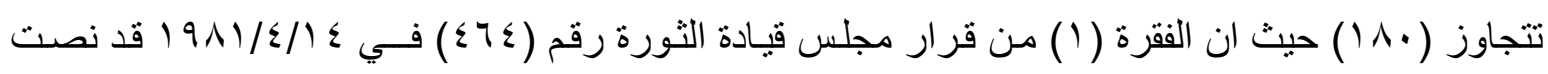
على يمنح المحـالون على التقاعد مـن اعضـاء الهيئات التدريسية المشـولين بأحكام الفقرة (r) مـن المـادة 
الخامسة والاربعين من قانون الخدمة المدنية مكافاة تعـادل الرواتب الاسمية لمدة ستة اشـهر بمقياس الراتب

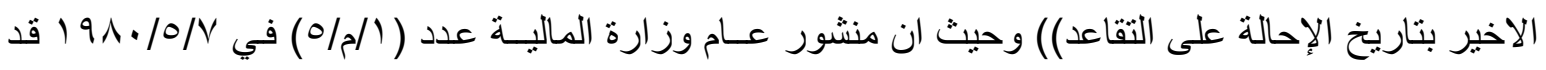
قضى من ان الموظف المحال على التقاعد ثانية يستحق رواتب الاجـازات الاعتيادية المتجمعة لله عن خدمتهـ

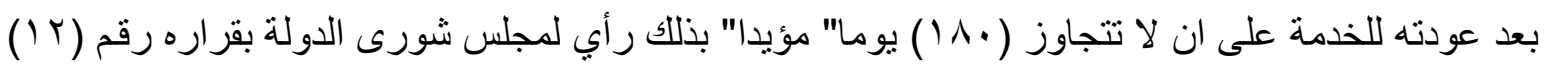
لسنة ، 191 الذذي قضـى باستحقاق الموظف ثانيـة متر اكم الاجـاز ات عند احالته للمرة الثانيـة على التقاعد وتأسيسا" على ما تقدم قرر المجلس بالاتفاق الحكم بالز ام المدعى عليهـا صرف استحقاق المدعي من مبالغ

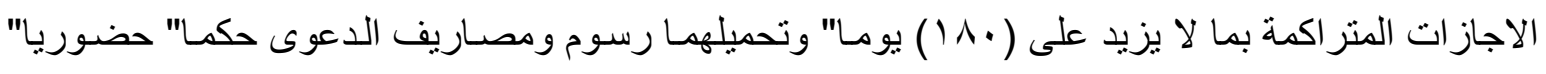

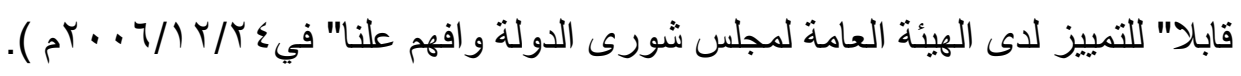
اما بالنسبة للمر أة العاملة في القطاع الخاص والمشمولة بقانون العمل فيختلف تنظيم اجازتها من مشرع لاخر فالمشرع المصري قد تضمن قانون العمل على ان تكون الاجازة على ثلاث حالات الحالة الاولى مدة خمسة عشر يوم للعاملة والتي لا تتجاوز مدة عملها سنة واحدة ولا تستحقها الا بعد مضسي ستة اثـهر ويبدأ

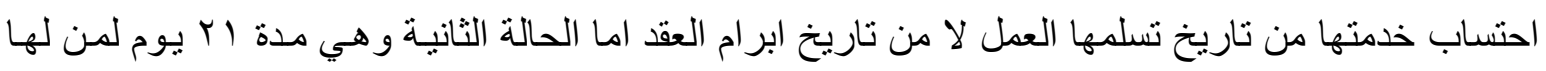
خدمة اقل من عشر سنوات والحالة الثالثة تكون مدة الاجازة شهر لمن تكون خدمتها اكثر من عشر سنوات او او

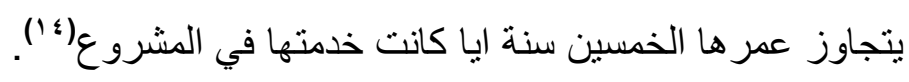
اما قانون العمل اللبناني فقد نصت المادة (9 ب)منه (( لكل أجير الحق في اجـازة سنوية خمسـة عشر يوما باجر كامل شرط ان يكون مستخدما في المؤسسة منذ سنة على الاقل .لرب العمل ان يختار تاريخ هذه الاجازة بحسب مقتضيات الخدمة وليس له ان يصرف الاجير او ان يوجه اليه علم الصرف خـلال الاجازة ))

اما بالنسبة لقانون العمل العراقي النافذ فقد فرقت المـادة (V0/اولا وثثانيا) بين حالتين الحالة الاولى

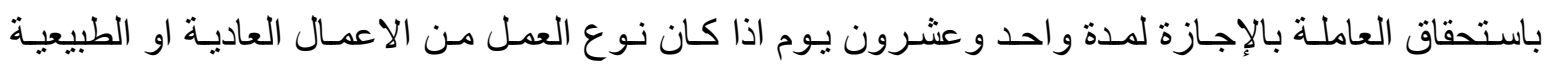

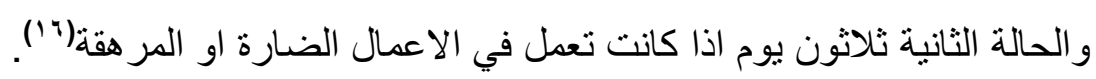

يلاحظ على المشرع المصري انه اعتمد على استحقاق مدة الاجـازة للعاملـة على خدمـة وعمر العاملـة و هو ما خالف به موقف المشرع اللبناني وكذللك العر اقي مخالفة نسبية فقد اعتمد على استحقاق مدة الاجازة على نوع وطبيعة العمل ـ. ونرى بـان اتجاه المشرع المصري و العر اقي قد سـار على النهج الصحيح الا ان المشرع العراقي كان موفقا اكثر عن غيره فيمـا يتعلق بنوع العمل ، كذللك اضـافت الفقرة الثالثة من المـادة

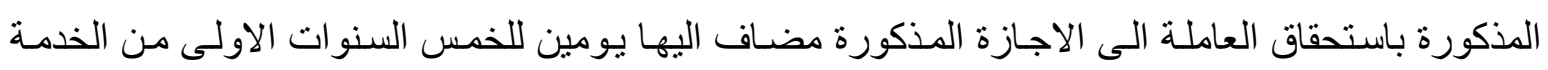
ويومان للخمس السنوات التالية وثلاثة ايام للسنوات اللاحقة اذا كانت خدمة العامل لدى صاحب العمل . كذلك ان المشرع اللبنـاني منح العاملـة بأخذ الاجـازة لكن بعد مرور سنة من خدمتها وهو ايضـاً مـا

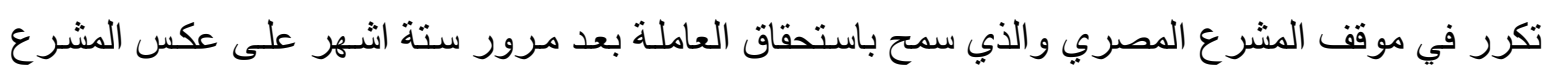

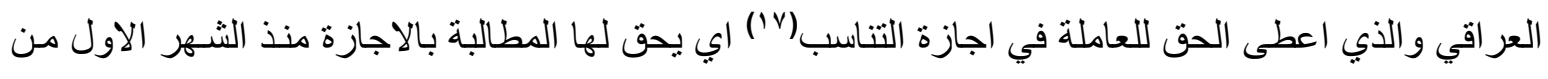
استلامها للعمل وفقا للمادة ( / / رابعا) من قانون العمل العر اقي و هذه ايضا يحسب لموقف المشرع العر اقي. 
و اذا كان المشرع قد نظم مدد ومو اعيد الاجازة بالنسبة للعاملة فالتسـاؤل الذي يبرز بهذا الصدد هو مدى امكانية الاتفاق على مدد الاجازة في عقد العمل اكثر او اقل من المدد المنصوص عليها في قانون العمل للاجابة على ذلك يجب ان نفرق بين حالتين الحالة الاولى اذا كانت اكثر من المدة المحددة فهنا الاتفاق يكون صحيحاً وذلك لان هذه المدد تمثل الحدود الدنيا للعاملة وبالتالي تكون بمصلحة العاملة والحالـة الثانيـة امـا اذا كان الاتفاق في العقد يعطي للعاملة اقل من المدة المحددة في القانون فان هذا الاتفاق يكون باطل وذلك لتعلق هذا الامر بالنظام العام.

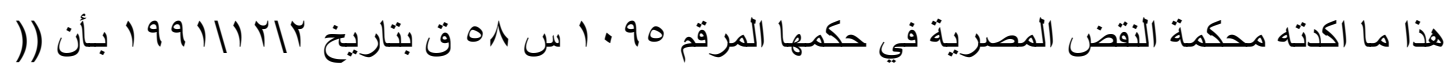
ان اجازة العامل بكافة انو اعها عزيمة من الثار ع دعت اليه اعتبار ات من النظام العام و هي ايام معدودات في

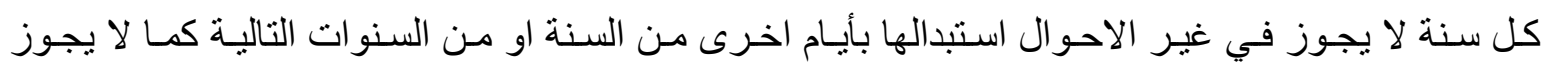

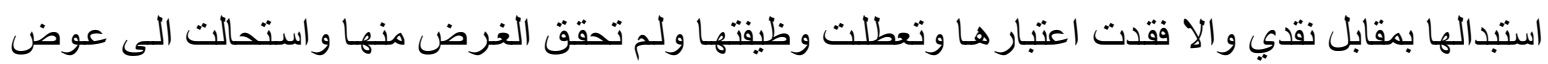
نقدي يدفعه صاحب العمل الى العامل وفي ذلك مصادرة على اعتبار ات النظام العام التي دعت اليهه ومخالفة لها كمـا ان تخويل العامل الحق في التراخي في اجازتهـ ثم المطالبـة بمقابـل لها مؤداه ان بستطيع بإر ادتـه المنفردة ان يحمل صاحب العمل بالتزام هو عوض حقه وليس عن حق بينهما لا يد لله فيه وهو حسال يختلف عما اذا حل ميعادها ورفض صاحب العمل الترخيص له بها فانه يكون حينئذ قد اخل بـالتزام جوهري ولزئهـ

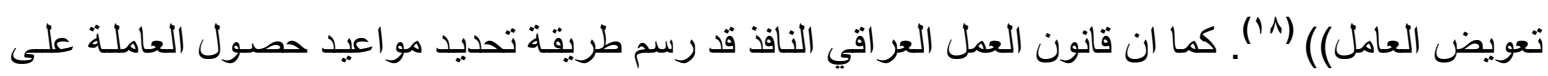
اجازتها في المادة(VN) من انه لصاحب العمل ان يضع نظام داخلي يبين فيه المو اعيد التي تمنح فيها العاملـة

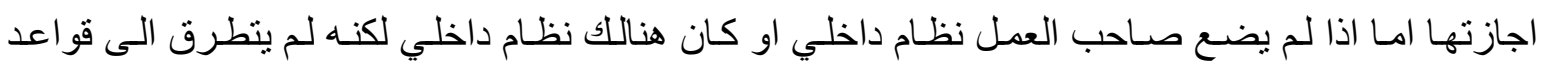

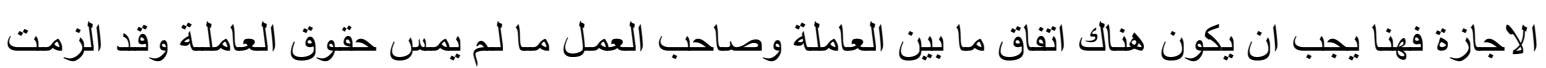

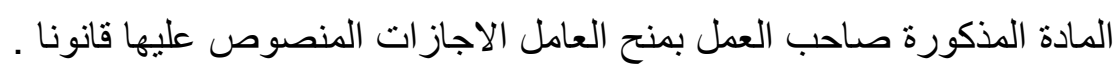
يلاحظ على ما سبق بـان العوض النقدي يكون من استحقاق الموظفة في القطاع العـام او العاملة في القطاع الخاص للاجازة غير المنتفع بها اثناء الخدمة او بعد انتهاء خدمتها .

\section{الامبلب الثاني- الاجازة الدراسية}

ان تقدم الدول مرتبط بالنظم السياسية المتبعة والمتعلقة بالجهاز الاداري ونشـاط الاخير مرهون بتتمية

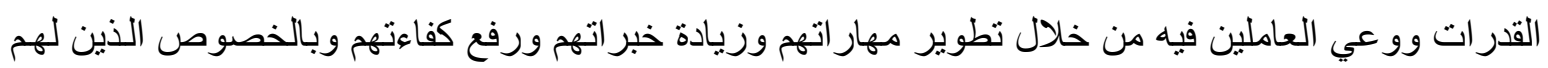
الرغبة والاستعداد للحصول لهذا الامر والذي من خلاله يعكس صورة ايجابية على و اقع الدولة وتقويمها من حيث تطوير الجهاز الاداري فيها فتحسين المستوى العلمي يحظى بأهمية خاصـة من قبل المشرع العراقي

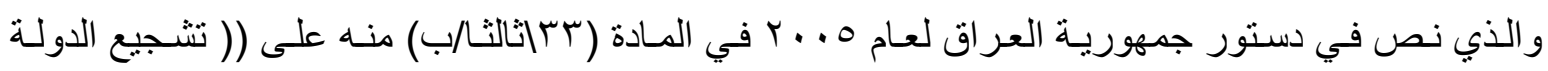
البحث العلمي وترعى التفوق والابداع والابتكار ومختلف مظاهر النبوغ)).

فالاجازة الدر اسية هي الفترة التي تمنح للموظفة لغرض الدراسـة او للتحضير للامتحانسات وتأديتها في مر احل التعليم المختلفة بناءا على طلبها ـ و هو امر تكرسه اغلب التشريعات المقارنة الخاصة بالوظيفة العامـة و التي اعترفت للعاملة في القطاع العام او الخاص على حقها في الاجازة الدراسية. 


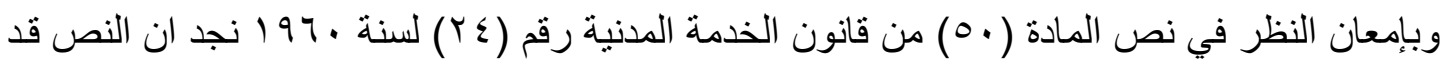
تضمن نو عين من الاجازات .

النوع الاول اجـازة دراسية خـارج القطر: والذي تكون حصراً للذين يحملون شـهادة جامعيـة اوليـة او عليا شريطة ان تكون لهم خدمة فعلية في الوظيفة ولمدة سنتين .

اما النوع الثانى اجازة در اسبة داخل القطر : لغرض الحصـول على شهادة جامعية اوليـة او دبلوم بعد دراسـة

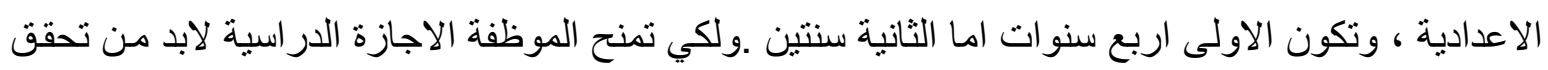

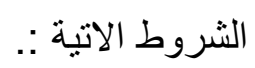

\section{الوَأ : الشمادة}

تعد الثهادة الحاصلة عليها الموظفة احدى الثـروط المهمـة التي تؤهلها لاكمـال در استها هذا مـا نص

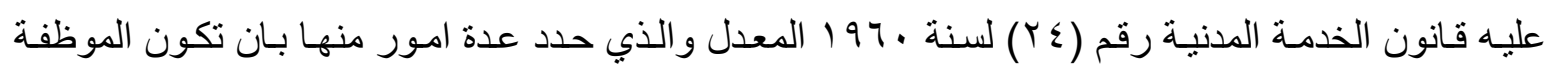

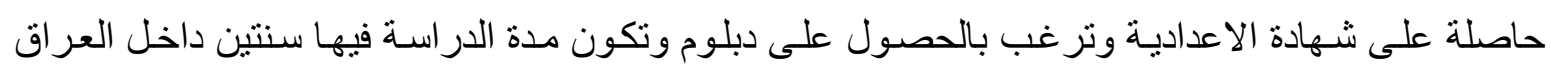

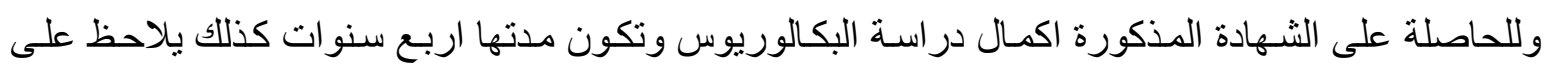
قانون الخدمة المدنية انه لم يتضمن نص يجيز تمديد الاجازة الدراسية للموظفة للحصول على شهادة اولية

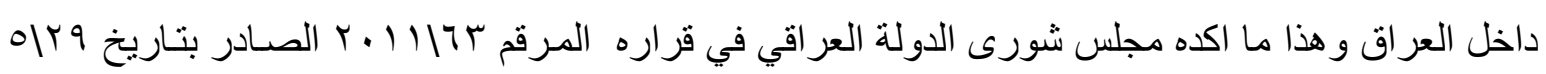

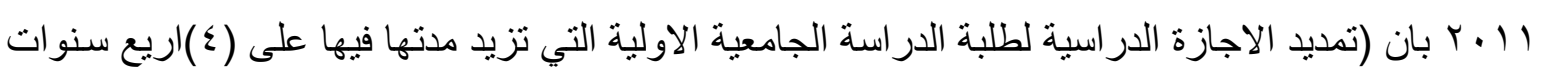

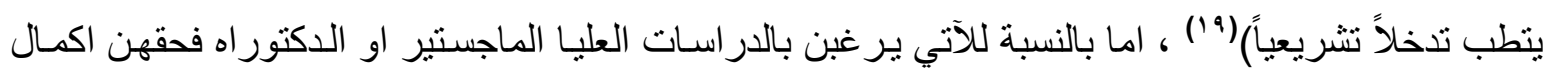
در استهن داخل او خارج العراق وفق الثـروط المطلوبـة وفي كل الاحو ال يجب ان تكون الثـهادة الحاصلة

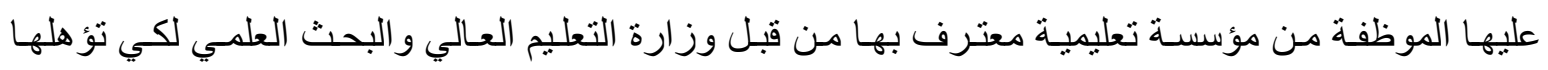
لاكمال در استها كذلك ايضاً يجب حصولها على قبول من الجامعة او الكلية او المعهد. كذلك يجب انب ان تكون الدر اسة في موضوع الاجازة على تماس مباشر بالوظيفة التي تشـلها مـع تطابقها باختصـاص الثـهادة التي

\section{ثانياً : الفدمهة الفعملية}

نصـت المـادة ( الولاًا | )مـن قـانون الخدمـة المدنيـة العر اقي (للوزير المختص ورئيس الجهـة غير المرتبطة بوز ارة منح الموظف الذي يحمل شهادة جامعية اولية او عليا واكمل سنتين في خدمـة وظيفية فعلية

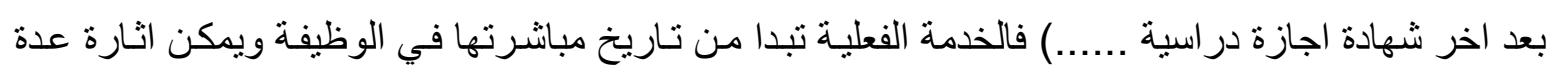
تساؤلات بهذا الصدد : هل خدمة المحاماة تمثل خدمة فعلية ؟ علما بان هذه الخدمـة تم احتسـابها خدمـة فعلية

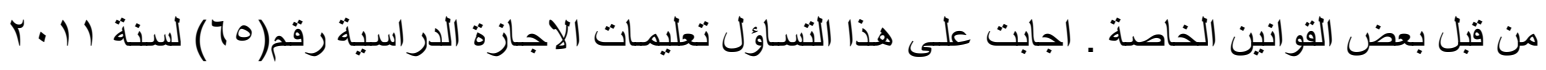

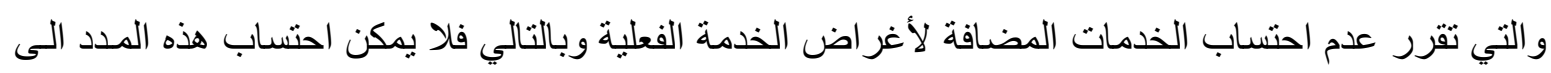

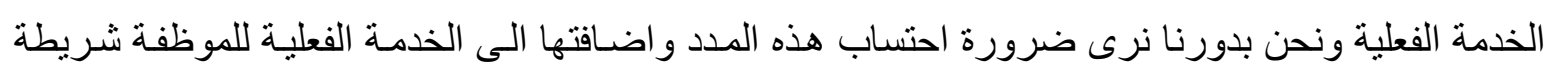
ان تجناز سنة التجربـة ونجاحها في التقييم فنجاحها في هذه السنة هو للتأكد من كفاءتها في اداء اعمالها 
الوظيفية وبما ان خدمة المحاماة ايضاً كانت قد مارست فيها اعمال فعلية فلا يمنع من ذلك لذا ندعو المشرع العر اقي للنص على ذلك.

اما فيما تعلق بالموظقة بعقد فهل يحق لها المطالبـة بمنحها اجـازة دراسية ام لا؟ من خـلال مناقتــة تعريف الموظف في النشريعات العر اقية والذي جاء في قانون الخدمة المدنية بـالنص على إن:(( كل شخص

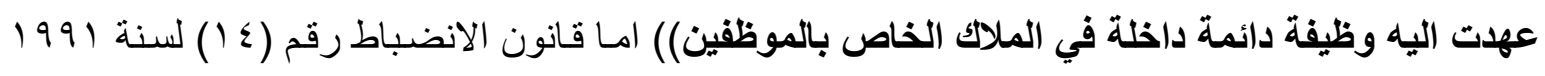
المعدل فقد عرفه بأن:((كل شخص عهدت اليه وظيفة داخل ملاك الوزارة او الجهة غير المرتبطة بوزارة ))

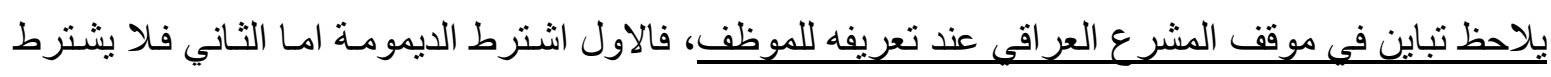
الديمومة في الوظيفة هذا ما اكده مجلس شورى الدولة العراق والذي اعترف لبعض الفئات من المتعاقدين مـع

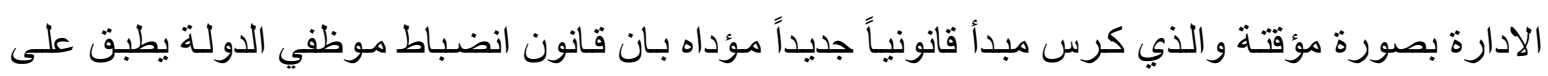

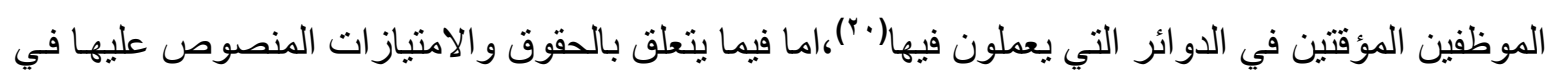

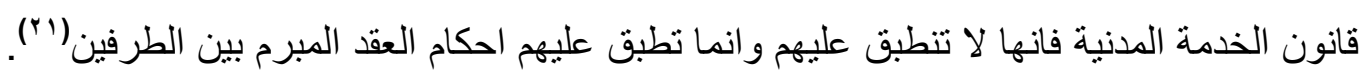

\section{فالاجازة الدراسية تعد من الحقوق التي يتمتع بها الموظف الدائم فليس للمتعاقد مـع الادارة الحق في} ذلك. كذلك يمكن اثارة مسـالة اخرى هل ان عضو مجلس المحافظة يعتبر موظف وبالتالي يستحق اجـازة دراسيةٌ ان النظام القانوني لمجلس المحافظة يعتبر ان عضو المجلس هو مكلف بخدمـة عامـة وليس موظفا

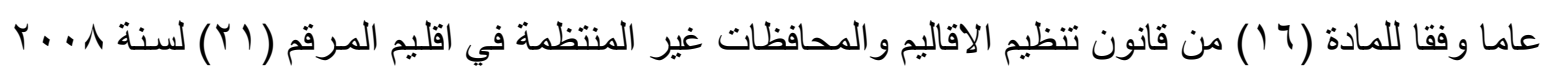
و هو ما كرسه مجلس شورى الدولة العر اقي بـأن (لا يجوز منح عضو مجلس المحافظة او المجلس المحلي اجازة در اسية طيلة مدة الدورة الانتخابية) .

اما فيما يتعلق بالمحافظ و القائم مقام ومدير الناحية وتمتعهم بالاجازة الدراسية نجد ان المـادة (Yr) من

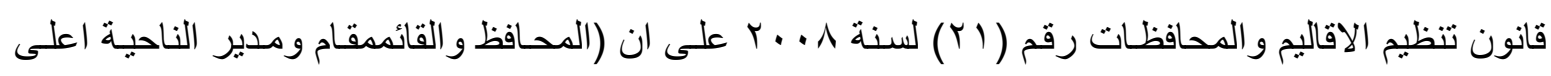

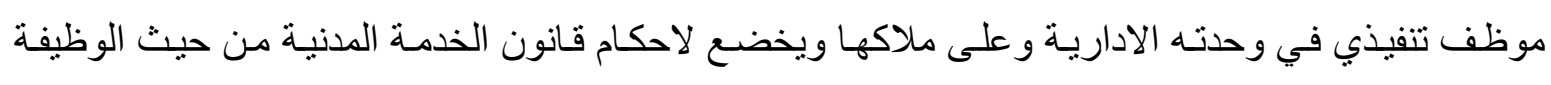

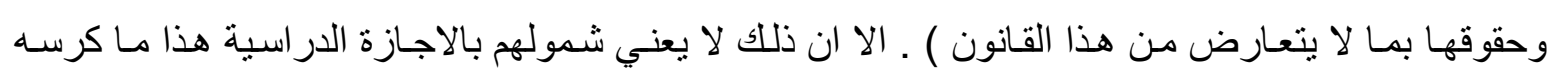

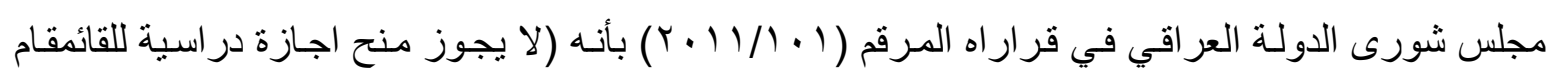

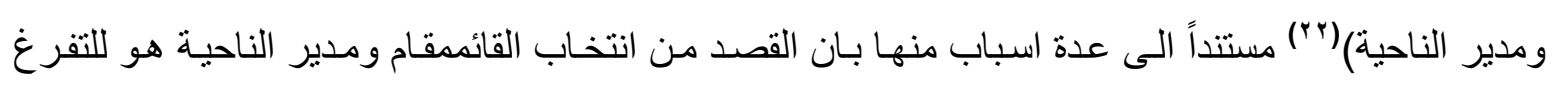
والانصر اف لادارة الوحدة الادارية طيلة مدة الدورة الانتخابية .

نجدر الاشتارة الى انه للادارة سلطة تقديرية في منحها الاجازة الا انها مشروطة بعدم التعسف وهذا مـا اكده مجلس شورى الدولة العر اقي في حكم له (ان دائرة المدعية سبق وان منحتها المو افقة على الاشتر الك في لهي

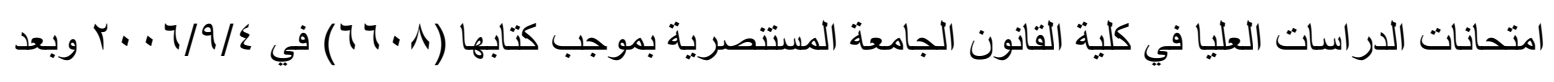
نجاح المدعية في الامتحانات وقبولها في الدراسات العليا الماجستير القسم العام الوارد في كتاب كلية القانون

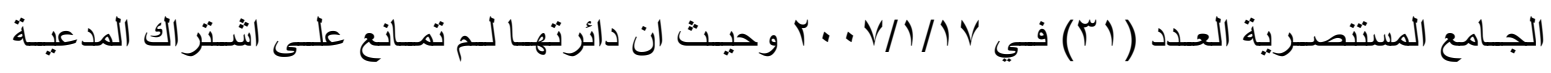
بالدراسات العليا وايدت ان لديها خدمه اكثر من عشر سنوات تهيئاً لقبولها ومن ثم اتمـام الاجر اءات القانونية المترتبة على ذلك ومن ضمنها الاجازة الدراسية فان رفض منحها الاجـازة الدراسية بعد ذلك يعتبر تعسفاً 
بحق المدعية خاصه وان دائرتها لها علم اليقين بانها مستمرة في در استها وقد اكملت الكورس الاول منها كمـا ان قانون الخدمـة المدنية وحسب مـا جـاء في نص الفقرة (r) من نص المـادة الخمسون قد اجــاز للوزير

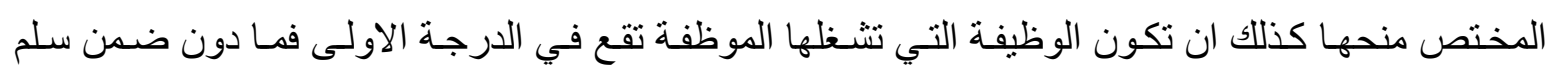
الرواتب و الدرجات كمـا في الملحق المبين في قانون رواتب موظفي الدولة و القطاع العام رقم (r Y) لسنة

\section{ثالثا : العمر والمعدل}

يختلـف العمـر و المعـدل حسـب الثــهادة التـي ترغـي فيهـا الموظفـة لإكمــال در اسـتها فقـي الـدبلوم و البكالوريوس لم ينص المشرع العر اقي على عمر معين ومعدل محدد امـا فيما يتعلق بالماجستير فقد حدد

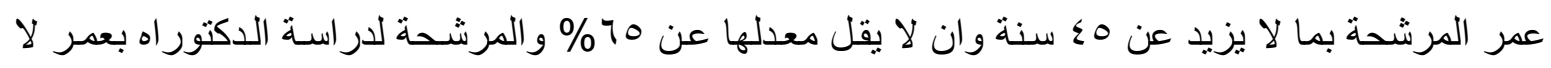
يزيد عن ••\% وبمعدل لا يقل عن •V\% ولللوزير الحق في منح الاجازة الدراسية للذي يقل معدلها عن

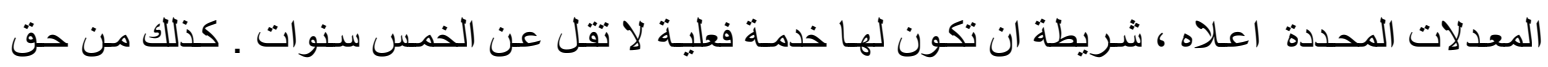
الموظفة ، طلب اجـازة دراسية ذات الاختصـاص الهندسي والطبي الذي يقل معدلها عن المعدلات السـابق ذكر ها، اذا كانت ضمن الخريجين الناجحين في الربع الاول ـ فالاستثناء يكون في المعدل دون العمر .

\section{المبمث الثاني- الاجازات الصمية}

بمـا ان الانسـان معرض لثـتى صـنوف الامـر اض ، الامـر الذي يتطلب مـدة زمنيـة لعـلاج المرض و التشافي منه، فلذا تكون الاجازة الصحية حق مشروع للموظفة و العاملة لتحقيق الثفاء و الر احسة الجسدية . و الاجازة الصحية لا تقتصر على مـا تقدم فقط ، اذ ان الموظفة والعاملـة قد تكون متزوجـة وتطهـح لإنجـاب الاو لاد خلال فترة الوظيفة والعمل، و هذا الامر يتطلب منحها مدة زمنية للأغر اض الحمل و الوضع. و عليه سيتم تقسيم هذا المبحث الى مطلبين، نخصص الاول للاجازة المرضية، و الثاني لاجازة الحمل .

\section{المطلب الاول- الاجازة المرضية}

التنظيم القانوني لاجازة الموظفة او العاملة نابع عن السياسة الاجتماعيـة المتبعة في الدولـة وبنـاء على

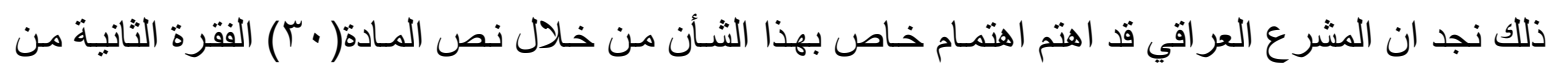

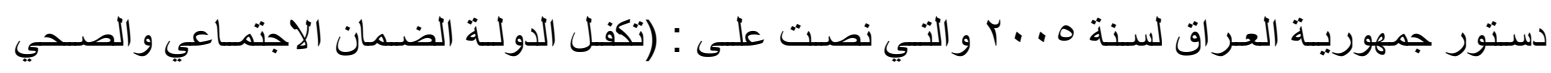

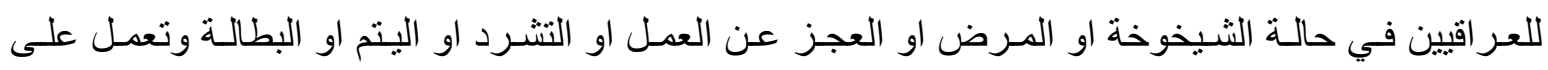

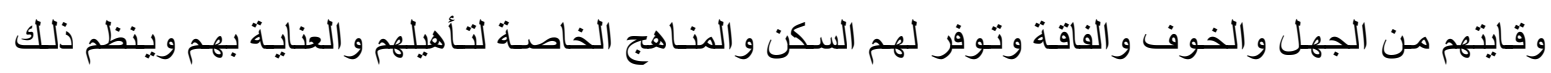
بقانون) كما نصت الفقرة الاولى من المادة ( ابr) من الدستور الحالي على ان (لكل عراقي الحق في الرعاية

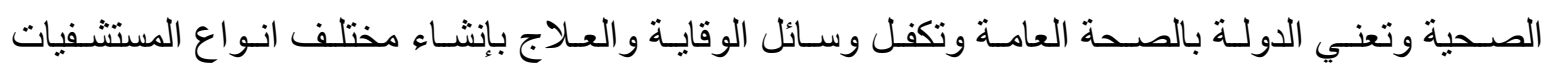

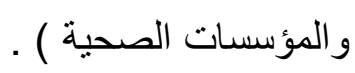

فالاجازة المرضية من الحقوق المهمة التي تتمتع بها الموظفة او العاملة سواء كانت في القطـاع العـام او الخاص و التي بإمكانها الاستفادة منها نتيجة مـا اصسابها من مرض فرض او حسادث يعيقها عن الاعمـال الموكلة اليها حسب طبيعة الوظيفة او في حدود العمل(rم). 
فالحكمة من منح العاملة لهذا النوع من الاجازة يحقق عدة اغر اض او فو ائد منها تمكنها من الاسترجاع

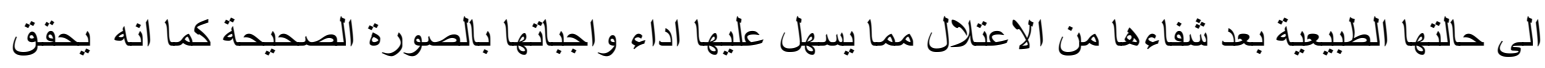
للجهاز الاداري المحافظة على صحة وسلامة باقي الموظفين او العـامليين من انتقال العدوى كمـا انه بيساهم

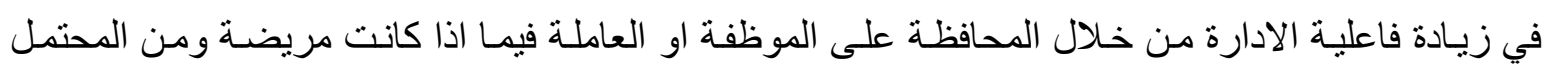
وقوعها بأخطاء اثناء عملها والذي ينعكس سلبا على ادارة المرفق الذي تنتمـي اليهـ. و واذا كانت القو اعد العامـة تقضـي بـأن الاجر او الر اتب مقابل العمل الا ان ذلك لا يمكن تطبيقهـ في حسال اصـابة الموظفة او العاملـة

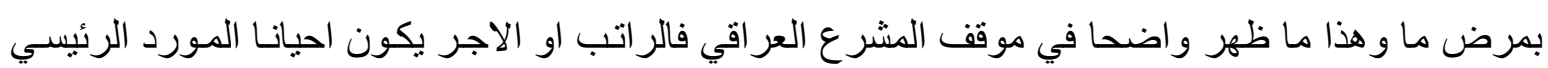
الوحيد لاعالة الاسرة وسد حاجات الموظفة.

وتختلف التشريعات المقارنـة في معالجتها للأسس القانونية التي تحبط بهذا النوع من الاجـازة سواء

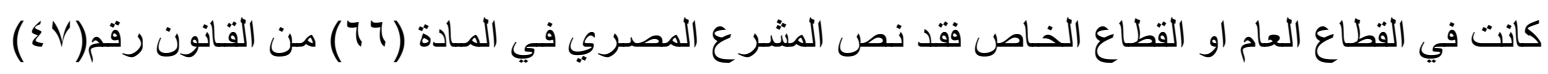

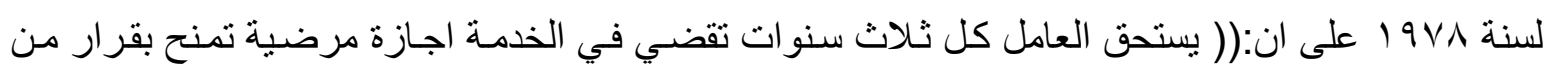
المجلس الطبي في الحدود الاتية:

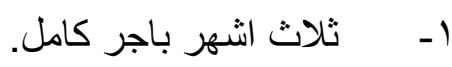

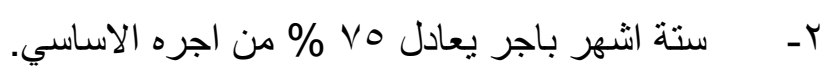

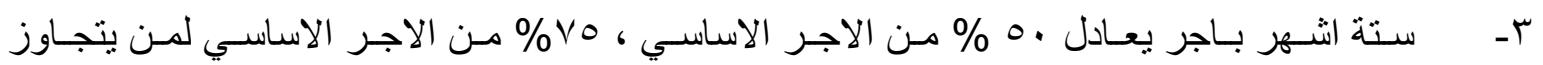
الخمسين من العمر.

وللعاملة الحق في مدة الاجازة المرضية ثلاث اثهر اخرى بدون اجر اذا قرر المجلس الطبي احتمـال شفائها وللسلطة المختصـة زيادة المدة ستة اشـهر اخرى بدون اجر اذا كانت العاملـة مصـابة بمرض يحتـاج

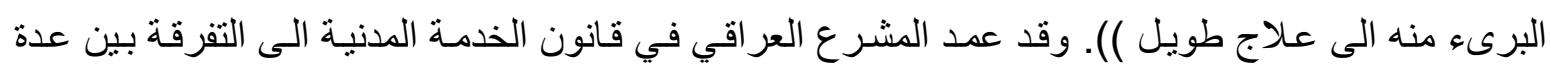
حالات فيما يخص الاجازة في المادة (ع ج) الفقرة (1) (1) منها: (أ- استحقاق الموظفة اجازة مرضية بمعدل ثلاثون يوماً عن سنة الخدمة.

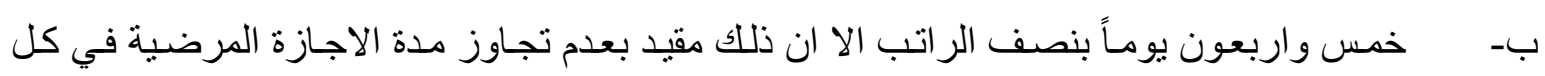
مرضها مئة وعشرون يوم حتى وان كان لها رصيد من الاجاز ات المرضية يزيد على ذلك )).

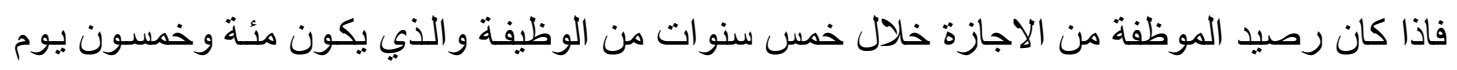
فمعنى ذلك انها لا تستحق سوى مئة و عشرون يوم وبر اتب تام واذا استوجبت حالتها منحها اجازة فهنا تستحق اجازة بنصف راتب على ان لا تزيد عن التسعون يوم امـا بالنسبة للقيد الثاني والذي نصـ عليه الفقرة (I) ب) من المادة ذاتها بان لا يتجاوز مجموع الاجازة المرضية خلال مدة الخمس سنوات التي تسبق انتهاء مدة الاجازة المرضية مائة وثمانون يوما بر اتب تام ومائة وثمانون يوم بنصف الراتب فهذا النص ينطبق اذا كانت الخدمة اكثر من خمس سنوات وكان لها رصبد من الاجاز ات المرضية حتى وان استخدمت جزء منها ففي الحالتين يتوجب على ذلك ان لا يزيد عن مئة وثمانون يوم بأجر كامل او مئـة وثمانون يوم بنصف الاجر

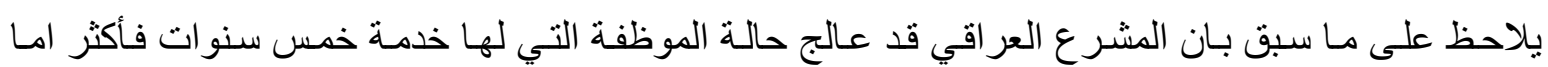


بالنسبة للموظفة التي تقل خدمتها على ذلك فهنا نكون امـام تجزئة للمدة وهذا مـا يفهم من نص المـادة (7 ؛ ) الفقرة الثانية والتي نصت على ان (( يجوز منح الموظف تحت التجربة لاول مرة اجازة مرضية لحد ثلاثون

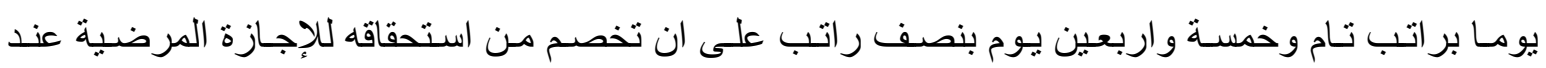
(اثبيته )

وبمقتضى الفقرة الثالثة من المسادة المذكورة أنفاً ، و التي منحت الموظفة اجـازة مرضية مدة اقصـاها سنتان اذا كانت مصابة بمرض السل او الجذام او اي مرض اخر لا يرجى شفاؤه ، او قد يستغرق علاجهه مدة

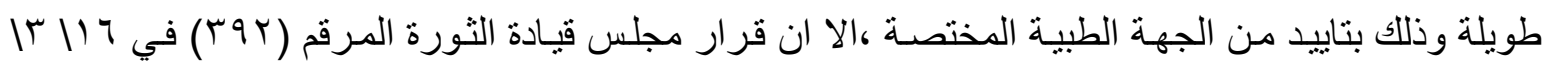
، 19 ا نص على ان :((اذا اصيبت الموظفة بمرض بستوجب علاجها مدة طويلة فيكون حقها اجازة مرضية خاصة بمدة اقصاها ثلاث سنوت وبر اتب تام وذلك بقرار من اللجنـة الطبيـة المختصـة)). وبالتـالي يعتبر قرار

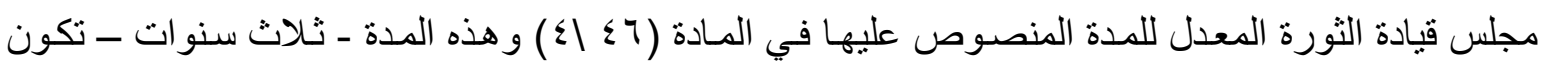

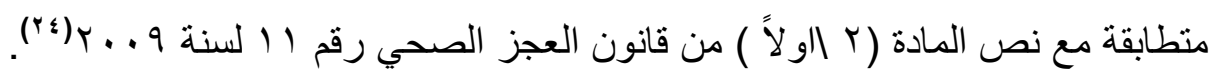
ويكون من حق الادارة التي تعمل فيها الموظفة الاحالة الى اللجنـة الطبية او بنـاءاً على طلب الموظفة ويكون قرار اللجنة قابل للاعتر اض امام اللجنة الطبية الاستئنافية خلال ( • ب) يوم من تاريخ تبليغها بـالقرار ويكون قرار الاخيرة بات (ro). هذا ما اكدته الهيئة العامة لمجلس شورى الدولة العر اقي في حكم لها بأن (منح الاجازة المرضية لمدة ستة اشهر يخضع لقانون العجز الصحي رقم (1) (1) لسنة 999 (19 وصدق قرار اللجنـة الطبيـة بـالقرار الصـادر

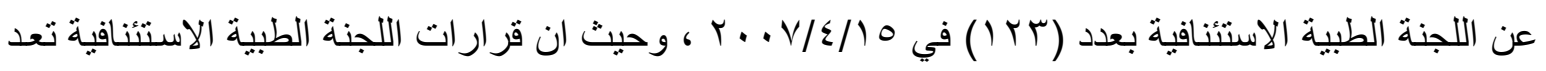

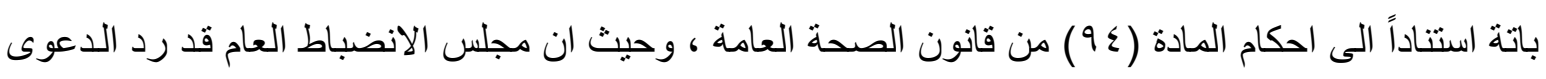
لكونها خارج اختصاصه الوظيفي فيكون قراره صحيحاً ومو افقاً للقانون قرر تصديقه ورد الطعن التمبيزي

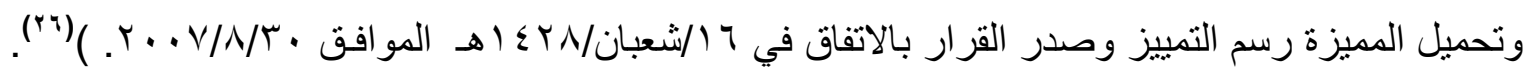
ويمكن ان يثار تساؤل مفاده هو هل يحق للموظفة المجازة بإجازة مرضية لمدة ستة اشـهر والمشمولة بمخصصات الخدمة الجامعية التمتع بهذه المخصصـات خلال فترة الاجـازة للاجابـة على هذا التسـاؤل يمكن الرجوع الى قرار الهيئة العامة لمجلس شورى الدولة العر اقي و الذي جاء فيه بأن( منح اجازة مرضية لمدة (7) ستة اثهر بتقرير مصدق في اللجنة الطبية المختصة في وزارة الصحة وحيث ان مـا ورد بأعمام وزارة

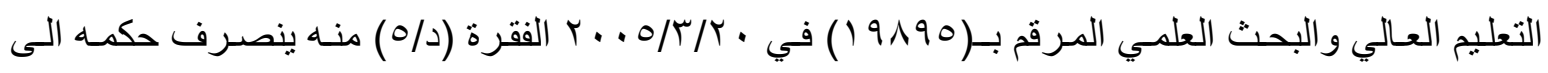

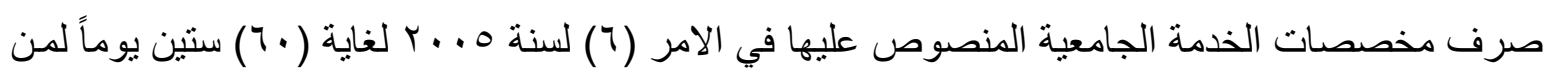

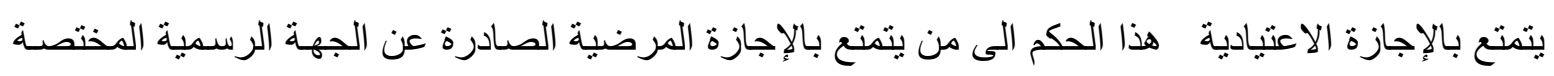
وحيث ان مجلس الانضباط العام قد التزم بوجهة النظر القانونيـة هذه وقضى بإلزام (المميز) المدعى عليه

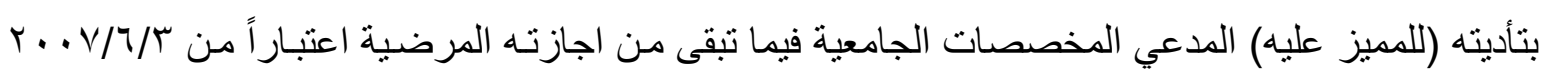

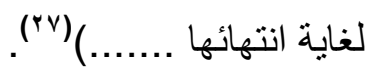




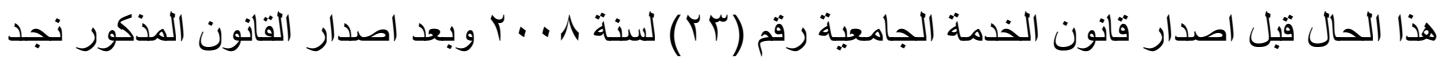
ان الموظفة المشمولة بمخصصات الخدمة الجامعية والمجازة بإجازة مرضية تتمتع بهذه المخصصـات وفق رف

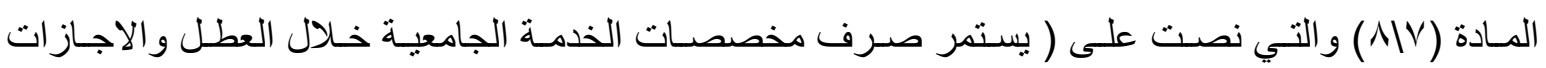
الاعتيادية و المرضية واجازات الوضع و الايفادات الرسمية ..... ).

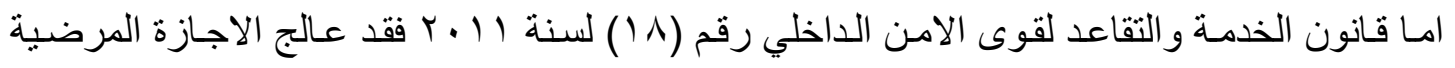
بصورة مختلفة من خلال نص المادة (rT) منه والذي تضمنت باستحقاق المنتسبة او الضابطة كما ياتي: 1 - اجازة مرضية طيلة مدة بقائها في المستشفى شريطة ان يكون دخولها للمستشفى ناثـئ عن الخدمة او من جر ائها وبراتب كامل. r- وتستحق ايضاً اجازة مرضية مدة بقائها في المستشفى لمدة اقصـاها مائة و عشرون يوم وبر اتب تـام لغير الاسباب سابقة الذكر.

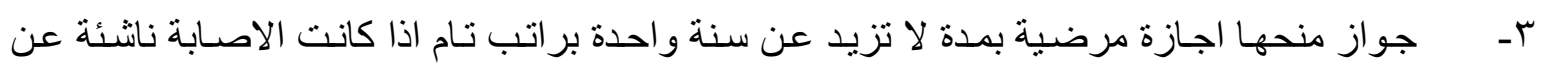
الخدمة والذي رتبت على كسر او جر ح او مرض بالاضافة الى المدة التي قضنها في المستشفى .

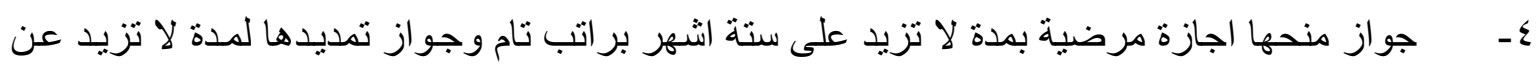
ستة اشهر بنصف راتب اذا كان سبب الاصابة خارجة عن الخدمة بالاضافة المدة التي قضتها.

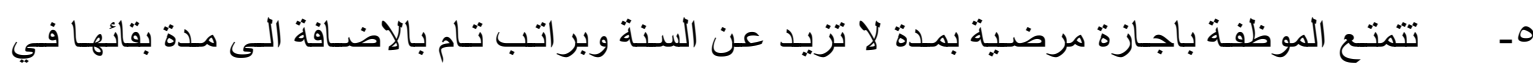
المستشفى اذا كانت مصابة بمرض معد او مرض لا يرجى شفاؤه وغير ناشئ عن الخدمة.

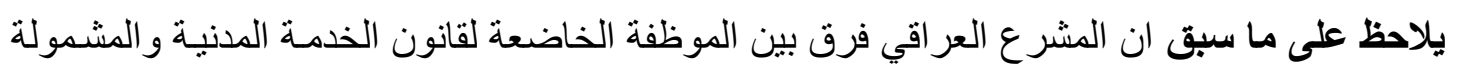

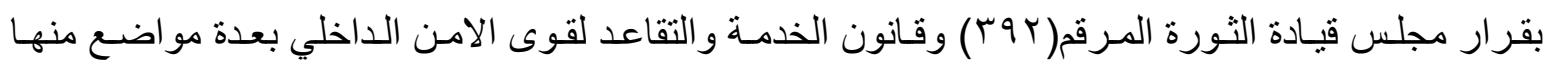
الاجازة المرضية الاعتيادية والتي لا يشترط فيها الدخول للمستشفى والتي تكون مدتها ثلاثون يومـا بموجب قانون الخدمة المدنية على خلاف ما جاء في قانون التقاعد لقوى الامن الداخلي من اشتراط دخول المستشفى.

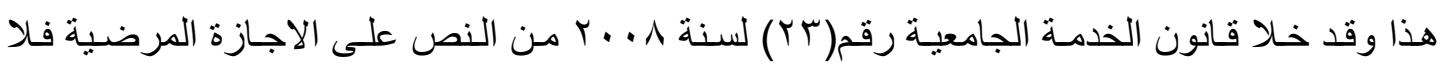
مناص من تطبيق احكام قانون الخدمة المدنية . اما بالنسبة الى للعاملة في القطاع الخاص و المشمولة بأحكام قانون العمل رقم (rV) لسنة 10 ـ ب فقد نص المشرع العر اقي على حق العاملة في الاجازة المرضية فقد نصت المادة (• ^) منه على استحقاق العاملة اجازة مرضية لمدة ثلاثثن يوماً في سنة العمل وتكون بأجر يدفع من صاحب العمل ويجوز تر اكم مدة الاجازة

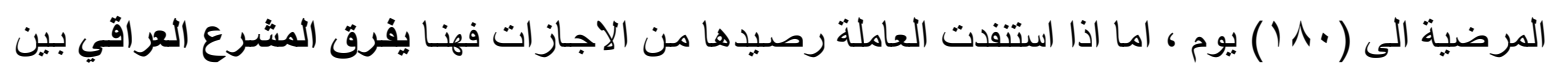
حالتين الحالة الاولى اذا كانت العاملة غير مشمولة باحكام قانون العمل فالعقد يعتبر موقوفا والحالة الثانية اذا كانت العاملة مشمولة باحكام قانون العمل ومضمونة في قانون الضمان الاجتمـاعي فتحسال الى قانون التقاعد و الضمان الاجتماعي وبمقتضى القانون الاخير نجده يصل الى نتيجتين في هذا الصدد النتيجة الاولى اذا كانت

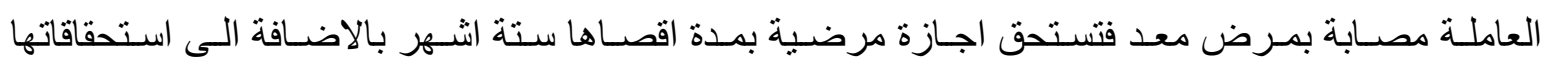
المنصوص عليها في قانون العمل وتستحق عوض عن هذه المدة ب (\%0\%) من منوسط اجرهـا للأشـهر 


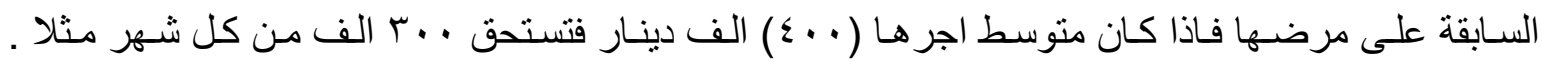

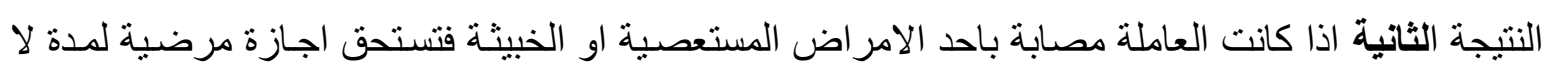
تتجاوز السنتين وتكون باجر كامل عن اخر اشتر اك دفع عنها.

ويثار التساؤل بصدد بعض الفئات من الموظفات و التي سمح لهن بالتمتع ببعض الامتياز ات ومنها

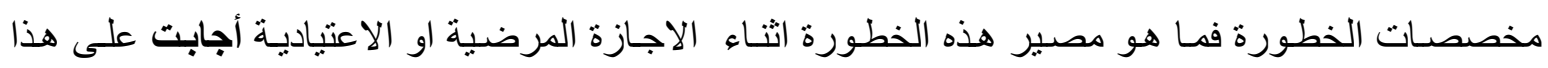

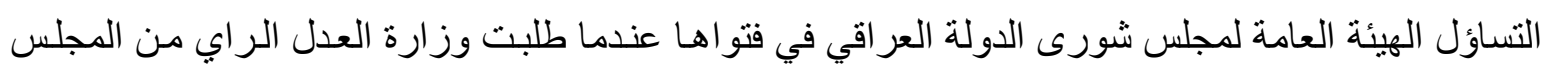

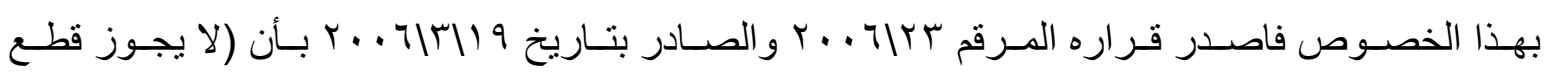
مخصصات الخطورة من منتسب دائرة الاصـلاح العر اقيـة في حالة تمتعهل بالاجـازة الاعتياديـة لمدة لا نزيد

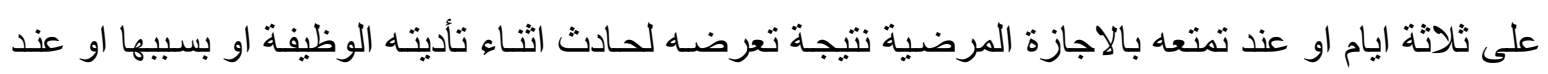
ايفاده داخل العراق لاغر اض رسمية او عند اعتقاله او حجزه لاسباب خارج ار ادته ).

الاملبب الثانب- الجازة الهمل والهضع

تحظى المر اة العاملـة سو اء كانت في القطـاع العـام او القطـاع الخـاص بأهتمـام من قبـل المشرع فيمـا يخص اجازة الحمل و الوضع لذلك فقد حرصت القوانين الخاصة تكريس هذا الحق ومنها قانون الخدمة المدنيـة العر اقي النافذ في المادة (T\& ) باستحقاق الموظفة اجازة حمل وو لادة وبمدة (Yr) يوم والتي يكون من حقها التمتع بما لا يقل عن (Yl) قبل الوضع وتكون براتب تام وهذا الحكم ايضا ينطبق على الضـابطة او المنتسبة

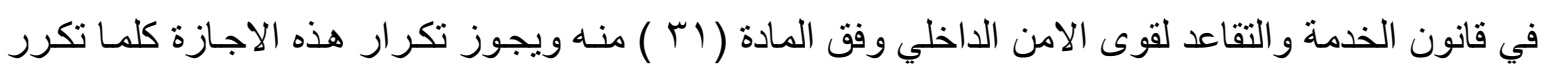

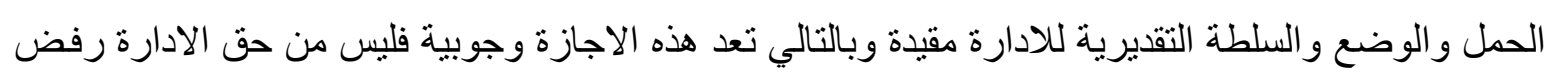

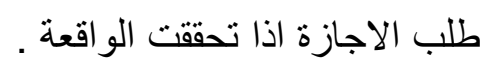
وفي لبنان تكون مدة الاجازة الحامل براتب تام وتكون مدتها (•ع) يوم (^^^وفي مصر تكون مدتها

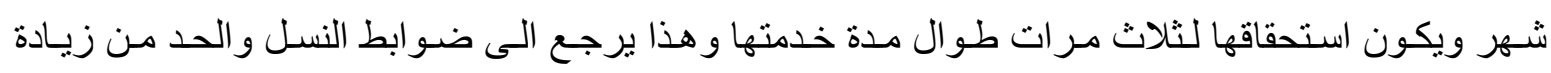

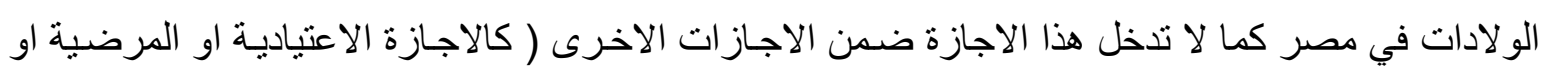
الخ ) كذلك لا يجوز تجزئة الاجازة (ra). اما فيما يخص النظام القانوني للعاملـة في القطاع الخـاص فقد نص المشرع المصري على استحقاق المر أة لاجازة الحمل والوضع . وفي العراق فقد كرس قانون العمل العر اقي في المـادة(AV) اجـازة الحمل والوضـع بمدة لا تقل عن ( ) (اسبوع ويحق لها التمتع بمدة الاجازة قبل ثمانية اسابيع من التاريخ المتوقع للوضع وتكون بشهادة طبيـة

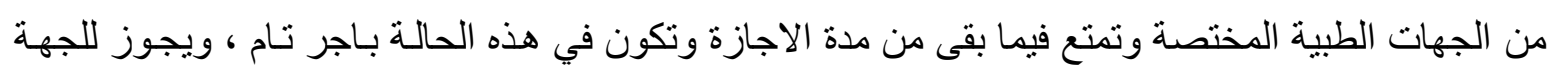

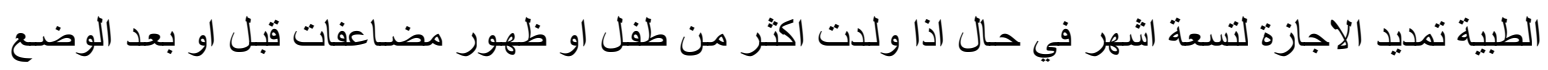
وتكون المدة الزائدة اجازة مضمونة وتطبق عليه قانون التقاعد والضمان الاجتمـاعي كذللك حقها بارضـاع طفلها لمدة لا تزيد عن ساعة واحدة في يوم العمل وتعتبر من وقت العمل ويبدو من المناسب دعوة المشرع 
العر اقي الى تكريس حق المر أة العاملة بالقطاع العام في قانون الخدمة المدنيـة العر اقي بإرضـاع طفلها. وقد حظر المشرع العر اقي اي عمل يعرض حالة المر أة المتمتعة بالاجازة للضرر او اي عمل مأجور.

ويمكن ان يثار تشـاؤل حول عمليـة الاجهاض هل يعتبر بمثابـة وضـع ام لا ؟ فـاذا اعتبر من قبيل الوضـع فـان من حقها التمتع بالإجازة المذكورة بالإمكان الاجابـة على ذلك بـان الاجهاض لا يعتبر وضـعا وبالتالي فليس من حقها التمتع بالإجـازة المذكورة حيث يكون باستطاعتها ان تتمتع في هذا الحالة باجـازة مرضية.( • (r)

\section{المبحث الثالهـ- الاجازات الاستثنانية}

تمتع الموظفة فضلاً عما تقلم بيانه بإجاز ات ذات طابع استثنائي قرر ها المشر ع استجابة لظروف تمر بهـا المر أة العاملـة و الموظفة ، مـن هذه الاجـاز ات العامـة والتي تشتـرك فيها مـع الرجل في ميدان الوظيفـة و العهـل ، واجـازات خاصـة بهـا مر اعـاة لتركيبهـا الفسيولوجي ووضـعها الاجتمـاعي، ومنهـا اجـازة الامومـة و العدة. و عليه، سنتناول هذه الاجـاز ات في مطلبين ، نتطرق في المطلب الاول الى الاجازات العامـة وفي المطلب الثاني الاجاز ات الخاصة .

\section{الإطاب الاول- الاجازات العامة}

نتنـاول ضـن هذا المطلب الاجـازة العرضية والتي تتمثل بتغيب الموظفة لامـر مفاجئ يعيقها عن الوصسول الـى محل عملها ، و الاجـازة الثانيـة وهي اجـازة اداء فريضـة الحج ، والاجـازة الثالثة وهي اجـازة المصاحبة الزوجية التي من خلالها تسافر المرأة مـع زوجها الى خـارج نطاق محل عملها لاغر اض حددها

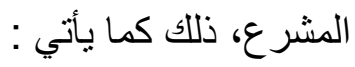

\section{الفرع الاول- الاجازة العرضية}

و هي التي تضطر فيها الموظفة لسبب طارئ او مفاجئ الى التغيب عن اداء مهامها الوظيفيـة دون اذن

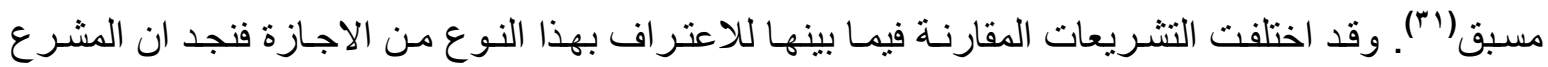

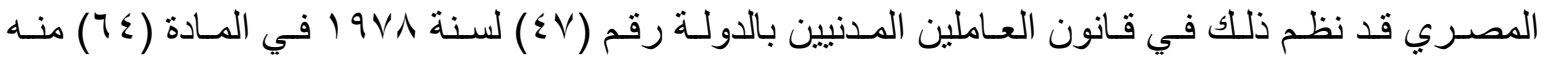
باستحقاق العاملة اجازة عارضة لمدة سبعة ايام في السنة وذلك لسبب طـارئ يتعذر معها الحصول على ايـة اجازة اخرى.

يلاحظ على ماسبق بان الاجازة العرضية او الطارئة بانها اجازة احتياطية اي يكون من حق العاملة شريطة استنفاده لرصيده من الاجاز ات الاخرى كالإجازة الاعتيادية.

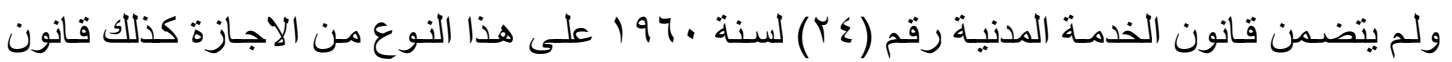
الخدمة والتقاعد لقوى الامن الداخلي وان كان الاخير قد نص على عدة انواع غير منصوص عليها في قانون الخدمة المدنية منها اجازة الزواج واجازة السفر خارج العراق اما فيما يتعلق بقانون العمل النافذ فقد نص في

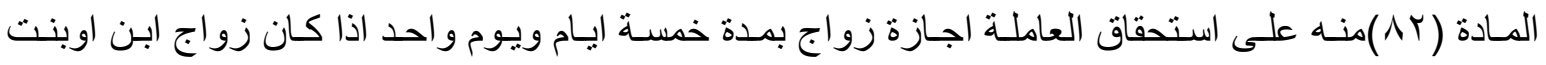
وخمسة ايام في حال وفاة الزوج او الاب او الام او الابن او البنت او الاخ او الاخت او احدوالدي الزوج. 
ونـن بلدورنا نـاعو المشرع العراقي الى تكريس هذا النوع من الاجـازة في قانون الخدمـة المدنية

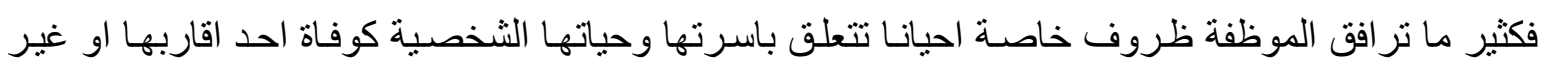
ذلك مـن الامسور ممـا يتعذر عليه الوصـول الى مقر عملها وابـلاغ رئيسها الاداري خصوصـا اذا كانت قد استنفلت رصيدها من الاجاز ات وبالتالي فنرى من الضروري النص على هذا النوع حتى ولو لخمسة ايام في

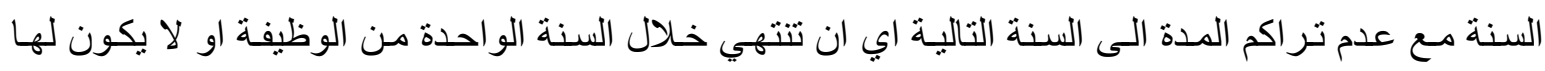
رصيد من الاجاز ات الاعتيادية كذلك دعوة المشرع العراقي الى النص في قـانون الخدمـة المدنية على اجـازة السفر خارج العراق واجازة الزواج لان في كل الاحوال الى هذه الانواع تكون بصورة استثنائية.

\section{الفرع الثاني- اجازة المهج}

الحج هو احد الفرائض التي فرضها الله سبحانه وتعالى على المسلمين في محكم كتابه العزيز حيث فال سبحانه (( ولله على الناس حج البيت من استطاع اليه سبيلاً)) فالاستطاعة شرط اساسي الذي توجب على لـى المكلف القيام بهذا الفرض ولو مرة واحدة. وتختلف التشريعات المقارنـة في معالجتها لهذا النوع من الاجازة

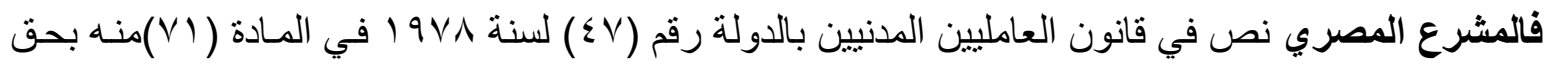

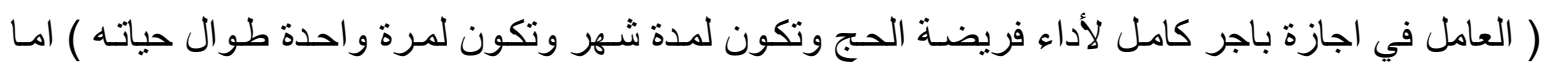

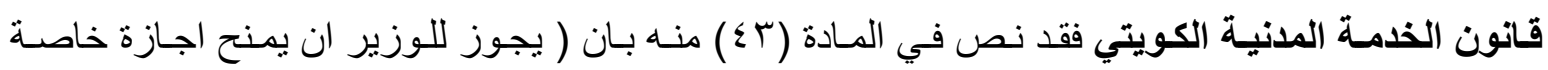
بمرتب كامل لا تحتسب ضـمن اجازته لمدة ثلاثين يومـا لاداء فريضـة الحسج ولا تمنح هذه الاجـازة الا مرة واحدة طو ال مدة الخدمة ويصرف مرتب الاجازة عند القيام بها ) يلاحظ على مـا سبق بـان القانون المصري قد اقر هذا الحق للموظفة والادارة بهذا الخصوص يكون لها سلطة مقيدة اما المشرع الكويتي فقد منح الادارة سلطة تقديرية هذا ما يفهم من النص أعلاه.

اما بالنسبة الى المشرع العراقي فقد تباينت مو اقفه بهذا الخصوص فقد نص في قانون الخدمـة والتقاعد لقوى الامن الداخلي على حق الضابطة او المنتسبة بمنحها اجـازة ولمدة (· ب) يوم وبراتب تـام لاداء فريضـة

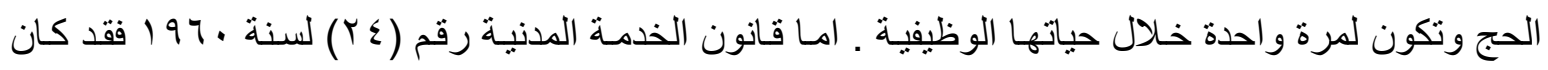
على عكس ذللك اذ خلا من النص على هذا النوع من الاجازة لذا فان الموظفة التي ترغب في اجـازة لاداء مناسك الحج فيمكن لها ان تستفيد من رصيد اجاز اتها الاعتيادية. وبناء على ذلك يبدو مناسبا دعوة المشرع العراقي الى النص في قانون الخدمـة المدنيـة على هذا النوع من الاجازات خصوصا وان الحج هو فريضة مقدة وواجب على كل مسلم وبالتالي فليس من العدل حرمان الموظفة التي ترغب باداء هذه الفريضـة خصوصـا اذا كان ليس لها رصيد من الاجـاز ات الاعتياديـة فالنص على ذلك يكون اكثر تمانشيا مـع النصوص الدستورية وفهم روح القانون ومن الحكمـة التي توخاهـا

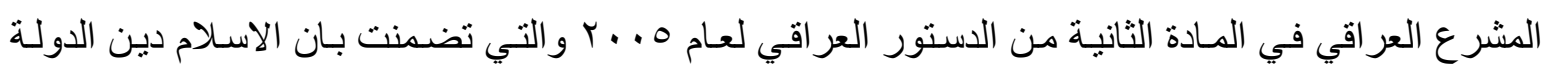
الرسمية والدستور ضامن لجميع الحقوق الدينية ولجميع الافر اد حرية العقيدة و الممارسة الدينية . اما بالنسبة الى العاملات بالقطاع الخـاص نجد ان المشرع المصري قد نص في قانون العمل رقم

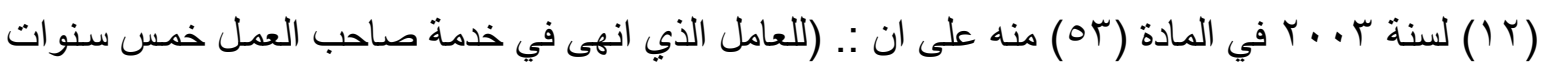


متصلة الحق في اجازة باجر كامل لمدة شهر لاداء فريضـة الحج او زيـارة بيت المقدس وتكون هذه الاجـازة مدة واحدة طو ال مدة خدمته)ومعنى ذلك بان اجازة الحج أو زيارة بيت المقدس حق للعاملة اذا رغبت في ذلك الا انها مشروطة بمضي خمس سنو ات في الخدمة وتستحقها مرة واحدة سو اء كانت الخدمة لصـاحب عمل كل واحد او اكثر كانتقال المنشاة من صاحب عمل الى اخر بالهبة او الوصية او الايجار بحكم المدة المتصلة . يلاحظ على ما سبق بان مدة الاجازة هي شهر وتكون بأجر كامل وتكون مستقلة عن باقي الاجازات.

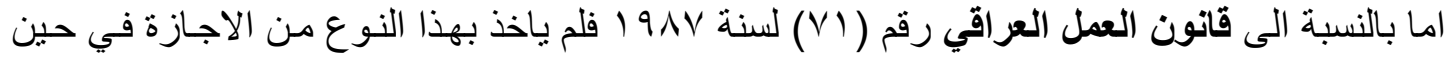

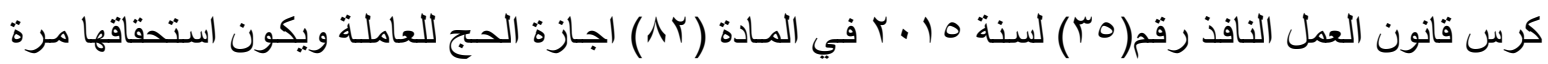
و واحدة وبدون راتب لذا ندعوا المشرع العراقي التتعديل المادة المذكورة و النص على استحقاق العاملـة الراتب للاسباب التي تم ذكر هـا بالاضـافة الى ان قانون العمل يهدف الى مصلحة العامل و النص على ذلك يصب بمصلحة العامل ويكون اكثر انسجاما مـع الدستور النافذ. امـا فيما يتعلق باجـازة العمرة فنلاحظ ان اغلب

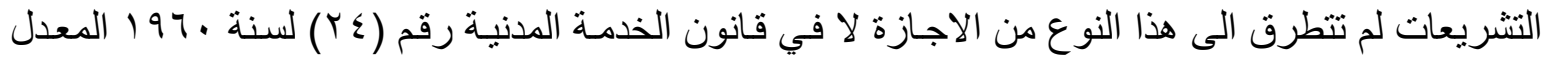

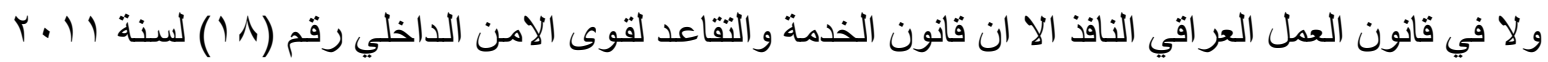
كرس هذا النوع من الاجازة في المادة (Tـ / ب) و التـي نصت على استحقاق العاملة الخاضعة لهذا القانون باجازة العمرة وبمدة (0 (10) يوم .

\section{الفرع الثالث- اجازة المسامبة الروجية}

لقد حرصت التشريعات المقارنة، ومنها المشرع العر اقي في الحفاظ على تماسك ووحدة الاسرة وجمع شملها من خلال النص على اجازة المصاحبة الزوجية. فقد نصت المـادة (ع §| § ) من قانون الخدمـة المدنية على جواز منح الموظف المتزوج و الذي يرغب بالالتحاق بزوجته خارج العراق وكذلك الزوجة الذي ترغب الالتحاق بزوجها خارج العر اق اذا كان الزوج موظف يزاول وظيفته خارج العراق او موكول بمهـة رسمية لمدة سنة فاكثر او كان طالب بعثة او مجاز در اسياً او متمتعاً بزمالة او متفر غ علمياً او طالب يو اصل در استه

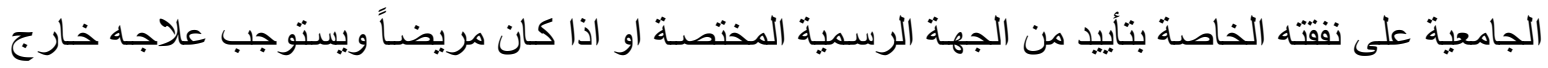

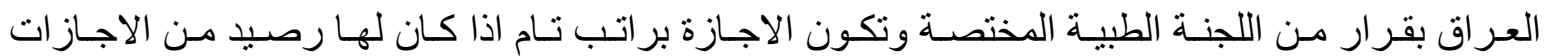
الاعتبادية اما اذا تجاوزت رصيدها من الاجاز ات الاعتيادية فان ذلك يكون بدون راتب ويكون حقها من هذا لهات الامتياز لمرة واحدة في حال وجود الزوج في مكان واحد. ويجوز للوزير المختص منح المعلمة او المدرسـة او الموظفـة المتزوجـة اجـازة اعتياديـة بـدون راتب لمن ترغب الانتقال الى محسال اقامـة زوجها ولا تتوفر الدرجة الثاغرة وفق المادة اربع واربعون خامساً.

\section{الاملب الثاني- الاجازات الغاصة}

تتضمن در استنا لهذا النوع من الاجاز ات كل من اجازة الامومة واجازة العدة ـ وسنتناولها تباعا ضمن 


\section{الفرع الاول- اجازة الاهومة}

و هي الاجازة التي تستحقها الام الموظفة من اجل رعايـة طفلها الصـغير الذي لم يتجاوز عمر سنة واحدة وقد نص المشرع المصري على هذا النوع من الاجازة في قانون العامليين المدنيين بالدولة رقم (Vع)

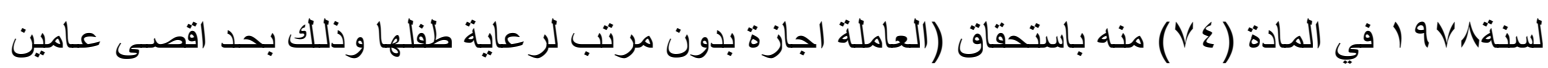
في المرة الواحدة وثلاث مرات طو ال حياتها الوظيفية ). اما قانون الخدمة المدنية العر اقي قد خلا من هذا النوع من الاجاز ات لكن تمت معالجـة هذا الامر في

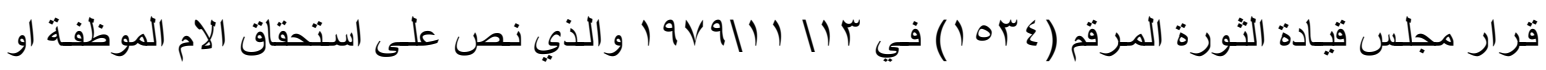
العاملة المضمونة في جميع دو ائر الدولة ومؤسسات القطاع الاشتر اكي باجـازة امومة بمدة لا تزيد على ستة اشـهر لتمكينها من رعايـة طفلها و الذي لم يبلـغ من السن اربع سـوات وتكون هذه الاجـازة بنصف راتب

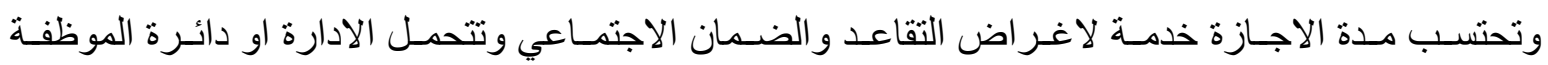

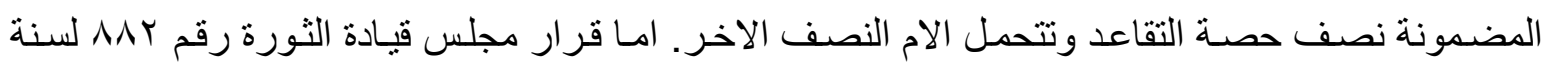
19N、V فقد جاء اكثر دقـة وتوصيلا والذي اكد فيه على استحقاق الموظفة اجـازة امومـة لمدة الستة الاشـهر الاولى بر اتب تام و الستة اللاحقة بنصف راتب ونص ايضا على العمل به من تاريخ نشره و استبعاد اي نص قانوني او قرار يتعارض مـع احكامهـ. امـا اذا ولدت الام الموظفة تؤام ، فمن حقها اجـازة امومـة وبمدة سنـة

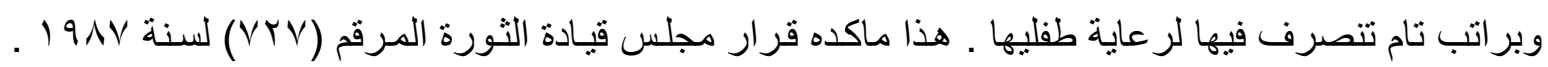

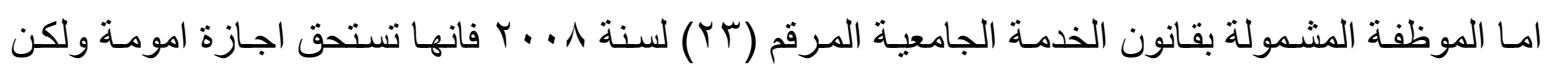
تكون بنصف الر اتب والمخصصات هذا ما اكدته المادة السابعة الفقرة الثامنة. وفي كل الاحوال فـان حق الموظفة في اجـازة الامومـة تكون لاربع مرات طوال خدمتها الوظيفية وتكون الاجازة بطلب مقدم من الام الموظفة وتبدأ من التاريخ المحدد في الطلب وصدور الامر بـه. ويحظر

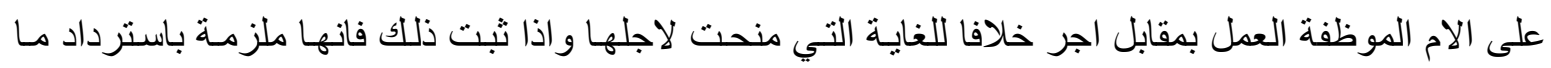
دفع اليها لصندوق هيئة التقاعد. اما المر أة العاملـة في القطاع الخاص فقد نظم المشرع المصري في قانون العمل رقم(r ( ) لسنة r . . r على حقها باجازة الامومة وبمدة لا تتجاوز السنتين وبدون اجر ولمرتين طوال

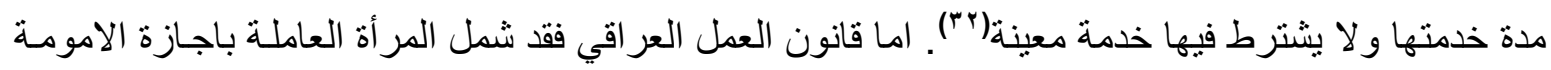
بمدة لا تزيد عن السنة وتكون بدون اجر تتصرف فيها لرعاية طفلها واذا ثبت بـان العاملة المجازة باجـازة الامومة قيامها بأعمال مأجورة وخالفت فيها اغر اض منحها الاجـازة اجـاز لصـاحب العمل الغاء هذه الاجـازة واعادتها الى عملها الاصلي من التاريخ الذي يحدده .

\section{الفرع الثاني- اجازة العدة}

وهي الاجازة التي تستحقها الموظفة المتوفى عنها زوجها ، ويحظى هذا النوع من الاجـاز ات بأهمية خاصة فهي واجب شرعي على المر أة المسلمة سواء كانت عاملة في القطاع العام او الخاص اذ قال تعالى في

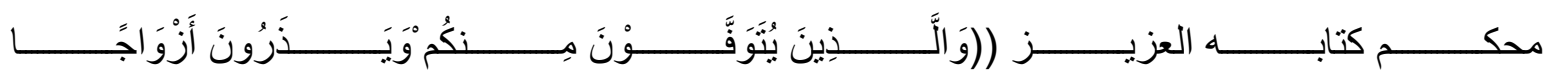

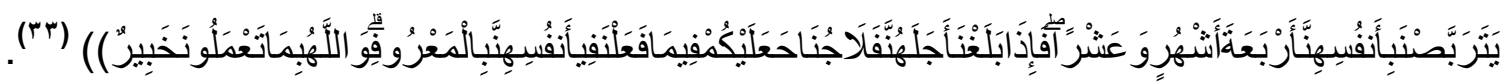




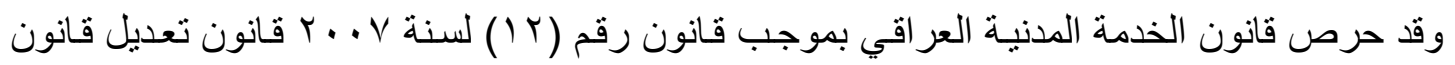

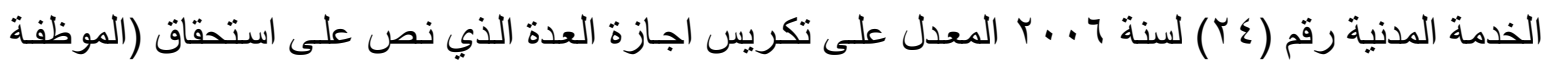

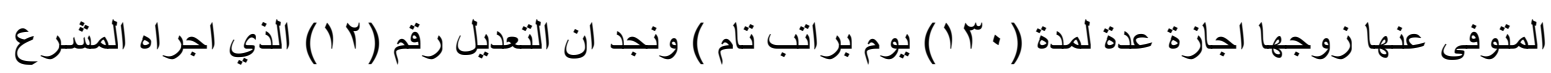

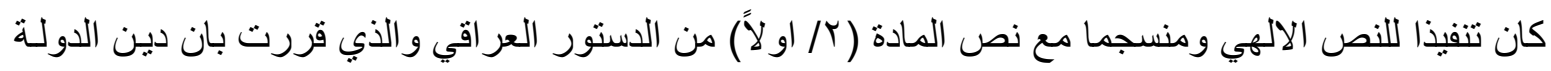

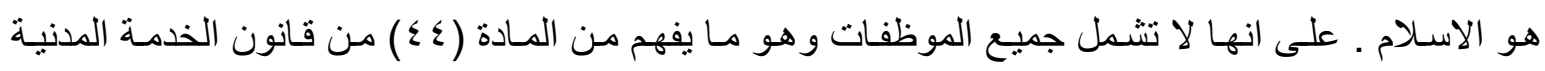
العر اقي النافذ و التي نصت على (( لا يستحق من يتمتع بـالعطلات المدرسية الاجازة المنصوص عليها في

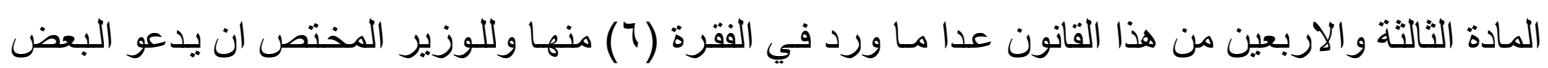
من هؤ لاء لاداء بعض واجبات التعليم خلال هذه العطلة التي يتمتع بها عن خمسـة واربعين يومـا في كل سنة در اسية)) وبالرجوع لنص الفقرة (7) نجدها تنص على اجازة الحمل و الو لادة اما اجازة العدة فهي في الفقرة (Y) وبالتالي فان الموظفات التي يتمتعن بالعطلات المدرسية غير مشمو لات بهذا النوع وهذا عجز تشريعي على المشـرع العر اقي معالجته مـن خـلال تكريس هذا النوع مـن الاجـاز ات علمـا ان مجلس شـورى الدولـة العر اقي قد كان له راي يخالف ذلك .عندما طلبت الامانة العامة لمجلس الوزراء الراي حول شمول المعلمـات

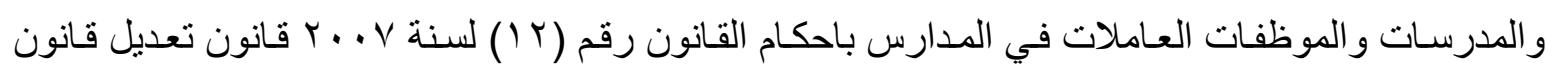

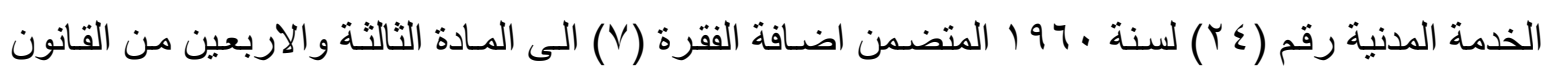

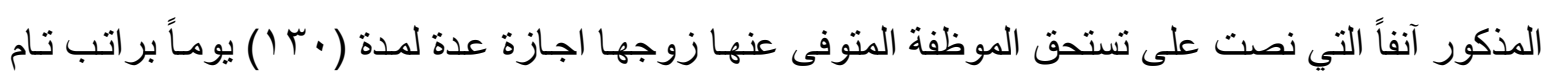

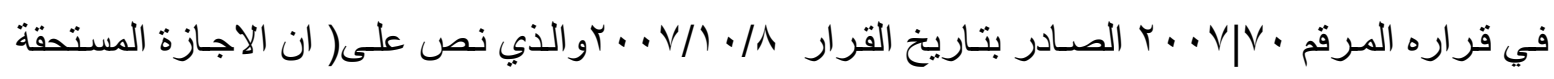

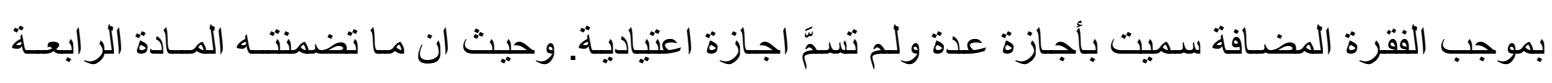
و الاربعون المذكورة آنفاً قد انصب على مـا تضمنته المـادة الثالثة والاربعون قبل اضـافة الفقرة اعلاه اليها.

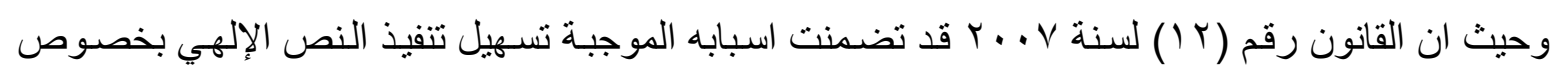
العدة الثر عية مما يكون النص القانوني كاثفاً لما تضمنه النص الإلهي ـوحيث ان مدلول الموظف ينصرف

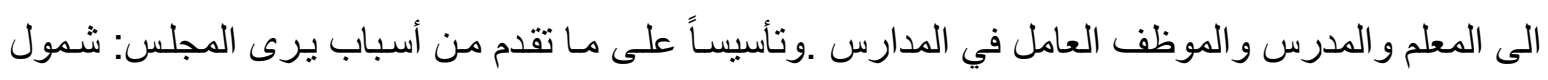
المعلمـات و المدرسـات و الموظفات العاملات في المدارس بإجازة العدة المنصــوص عليها في القانسون رقـم

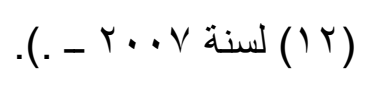

ومن جانبنا نرى بان اتجاه مجلس شورى الدولة لم يكن موفقا في فتو اه ، وذلك لان قانون التعديل رقم (Y T ( ) يجب ان يفهم بالمعنى الذي قصده المشرع ، فلو ار اد المشرع شمول هذه الفئات لنص عليها صـر احة بموجب قانون التعديل رقم (r ( ))، وبالتـالي فتكون الفتوى قائمسة على اسباب واعتبار ات غير قانونية ، كمـا ندعو المشرع العر اقي شمول هذه الفئات باجازة العدة ومساو اتها مع باقي الموظفات لان هذا النوع لم يخص فئة معينة وان اختلفت طبيعة العمل .

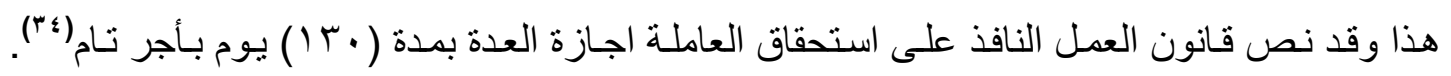

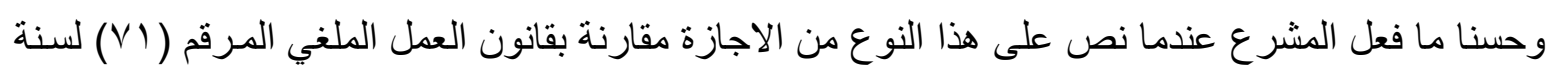

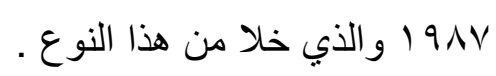


الخاتهة

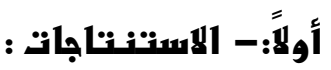

ا - ان المشرع العر اقي لم يفرق بين حق موظفة واخرى على اسـاس الاقدميـة والعمر بالنسبة لمنح الاجـازة الاعتيادية في القطاع العام، وهي تخضـع للسلطة التقديريـة للإدارة. امـا بالنسبة للقطـاع الخـاص فرق قانون العمل بين حالتين الحالة الاولى باستحقاق العاملة للإجازة اذا كانت الاعمال عادية او طبيعية ، و الحالة الثانية اذا كانت تعمل في الاعمال الضارة او المرهقة.

ז- يحق للموظفة اكمال الدر اسة الاولية او العليا بإجازة دراسية تمنحها لها الادارة توزاي مدة الدراسة بعد ان تمضـي عـامين من الخدمـة الفعلية في الوظيفة، ويجب ان تكون الدراسـة في موضـوع الاجـازة على تمـاس مباشر بالوظيفة التي تتـلها مـع تطابقها باختصـاص الثـهادة التـي تحملها، وحق الاجـازة الدر اسية لا تملكهـ

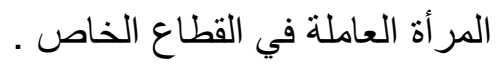

بـ الاجازة الصحية اجازة اساسية للموظفة التي يصيبها عارض صحي اثناء فترة الدوام، ولم يعطي المشرع العر اقي مدة اجازة واحدة للموظفة المريضة، حيث فرق المشرع بين حالـة واخرى، ومرض واخر، كمـا انهـ فرق بين الموظفة قيد التجربة والموظفة التي لديها خمس سنوات فعلية ـ وتتتمتع العاملة في القطاع الخـاص بإجازة مرضية قدر ها ثلاثون يومـا في سنة العمل وتكون بـاجر يدفع من صـاحب العمل ويجوز تر اكم مدة

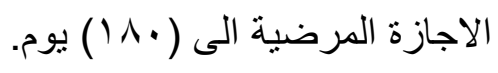

ك- تستحق الموظفة اجازة حمل وو لادة وبمدة (Yr) يوم و التي يكون من حقها التمتع بما لا يقل عن (Y) قبل الوضع وتكون براتب تـام، يجوز تكرار هذه الاجـازة كلمـا تكرر الحمل والوضـع والسلطة التقديريـة للإدارة مقيدة وبالتالي تعد هذه الاجازة وجوبية. ج- - استحقاق الام الموظفة او العاملة المضمونة في جميع دوائر الدولـة ومؤسسـات القطـاع العـام باجـازة

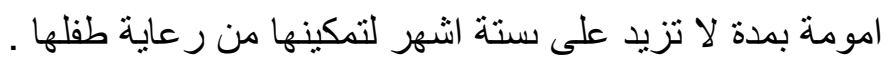

\section{ثانيا التوصيات :}

1 - السماح للموظفة بتمديد الاجازة الدراسية للدراسة الجامعية الاولية التي تزيد مدتها فيها على اريع سنوات من خلال تعديل تشريعي. كما ندعو المشرع الى التخفيف من حدة شرط المعدل للتقديم الى الدراسـات العليا

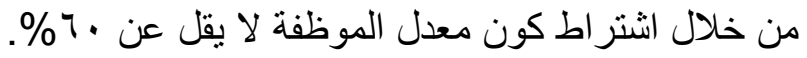

r- توحيد احكام الاجـازة الصحية في مـا يخص حالتي الموظفة تحت التجربـة والموظفة التي لديها خمس سنوات فعلية .

بـ دعوة المشرع العر اقي على احتساب خدمة المحاماة للموظفة خدمـة فعلية شـريطة ان تجتاز سنة التجربـة ونجاحها في التقييم، فنجاحها في هذه السنة هو للتأكد من كفاءتها في اداء اعمالها الوظيفية. و لان خدمة المحاماة قد مارست فيها اعمالا فعلية فلا ضير في احتسابها. 
ـــدعوة المشرع العر اقي الـى تكريس حق المـر أة العاملـة بالقطـاع العـام في قانون الخدمـة المدنيـة العر اقي بإرضاع طفلها اثناء الدوام ولو لفترة محددة.

هـدعوة المشر ع العر اقي الى تكريس الاجـازة الطارئـة في قانون الخدمـة المدنيـة فكثير مـا تر افق الموظفة ظروف خاصة احيانا تتعلق باسرتها وحياتها الثخصية كوفاة احد اقاربها او غير ذلك من الامور خصوصـا اذا كانت قد استتفدت رصيدها من الاجازات وبالتالي فنرى من الضروري النص على هذا النوع حتى ولو لخمسة ايام في السنة مع عدم تر اكم المدة الى السنة التاليـة اي ان تنتهي خـلال السنة الواحدة من الوظيفة او لايكون لها رصيد من الاجازات الاعتيادية.

T- كذلك دعوة المشرع العر اقي الى النص في قانون الخدمة المدنية على اجازة السفر خـارج العراق واجازة الزواج لان في كل الاحو ال الى هذه الانواع تكون بصورة استثنائية.

V- السماح للموظفات التي يتمتعن بالعطلات المدرسية بأجازة العدة مساو اة بأقر انهن من الموظفات من خـلال النص عليه في قانون الخدمة المدنبة النافذ . ل ^ـ دعوة مجلس شورى الدولة الى التزام في النص القانوني عند الإفتاء ، وذذلك لان قانون التعديل رقم (Y I ) يجب ان يفهم بـالمعنى الذي قصده المشـرع ، فلو ار اد المشرع شـمول هذه الفئات لنص عليها صـر احة ، وبالتالي فتكون الفتوى قائمة على اسباب واعتبار ات غير قانونية.

|

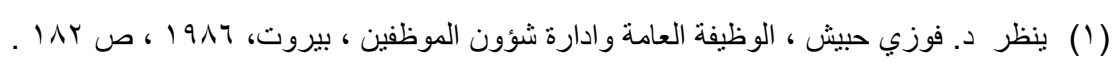

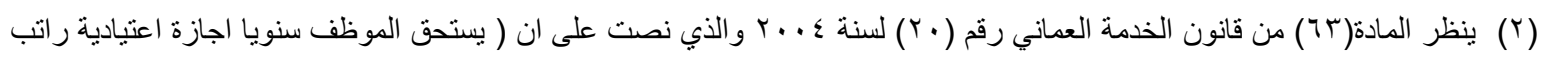

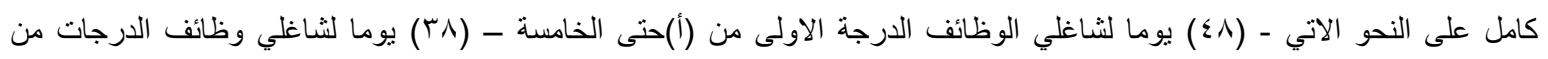

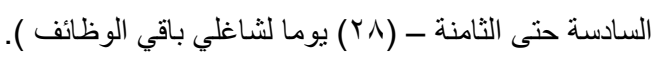

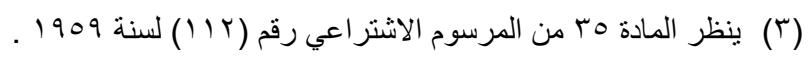

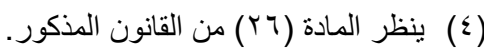

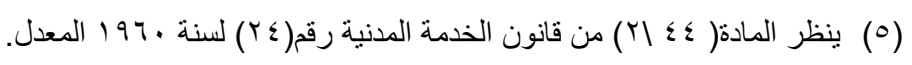

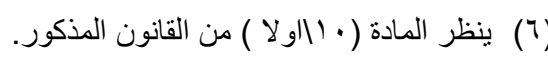

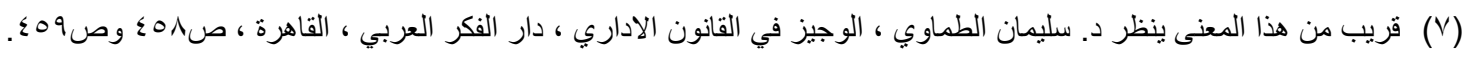

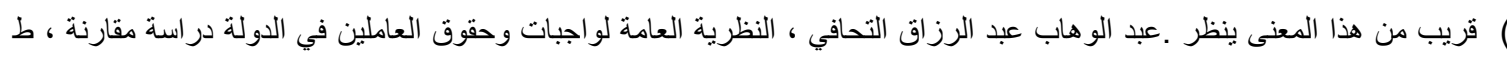

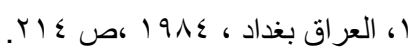

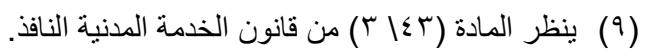

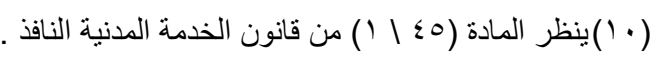

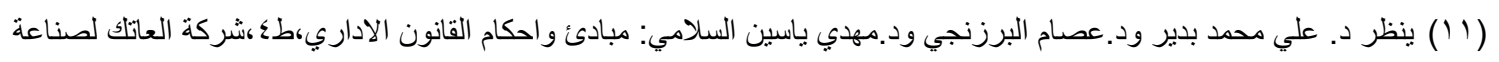

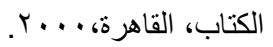

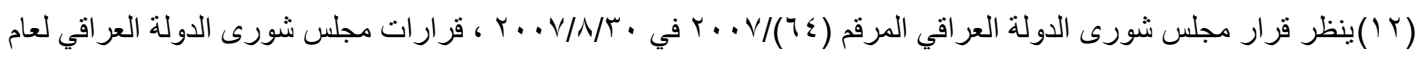

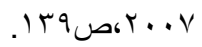

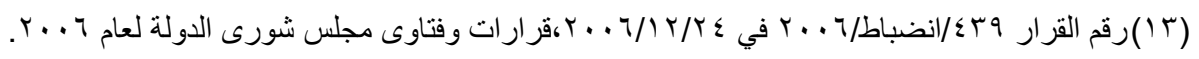

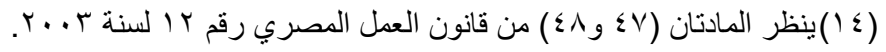

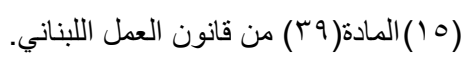




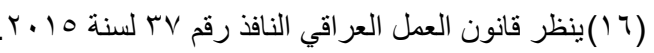

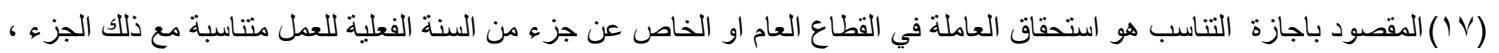

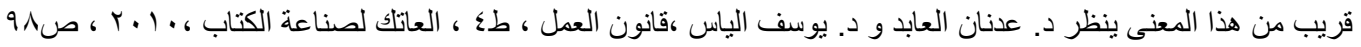

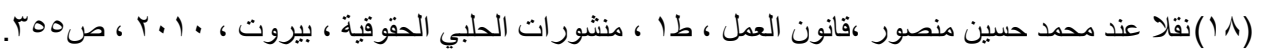

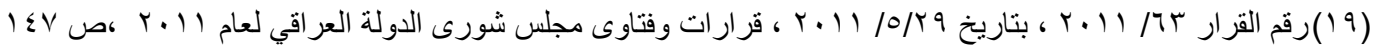

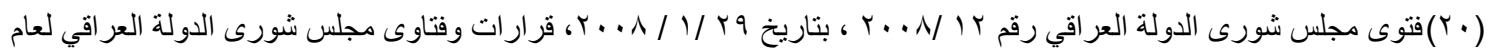
07 מ... Th

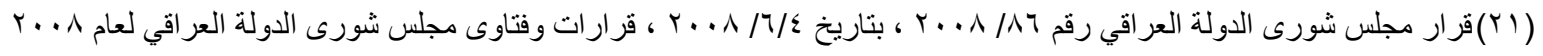
، ص I I

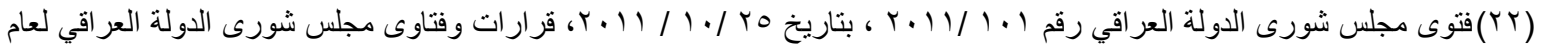

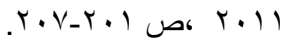

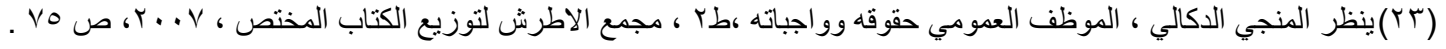

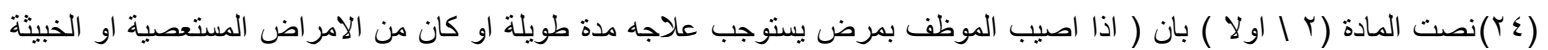
المحددة من وزارة الصحة فيمنح اجاز مرضية خاصة بر اتب تام مدة اقصاها (r) ثلاث سنوات بقر ار من اللجنة الطبية ).

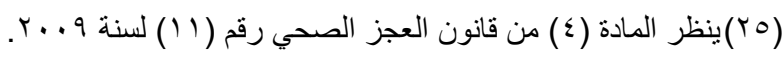

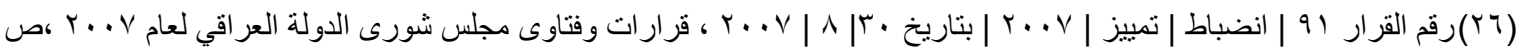

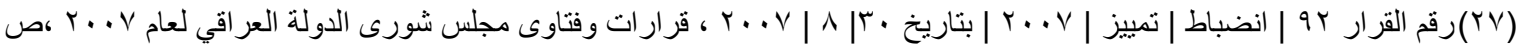

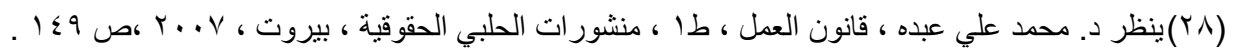

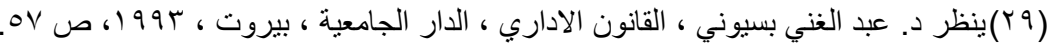

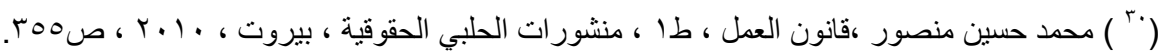

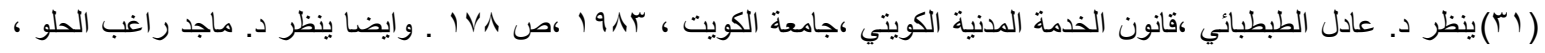

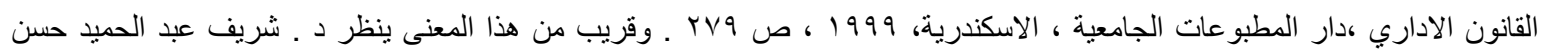

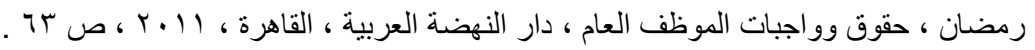

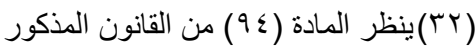

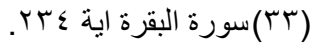

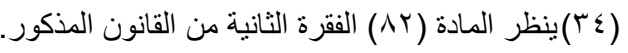

المراجع

أ - الكتب

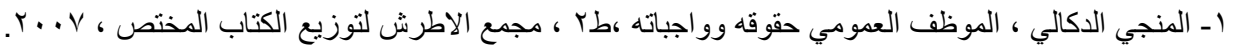
r- د. سليمان الطماوي ، الوجيز في القانون الاداري ، دار الفكر العربي ، القاهرة.

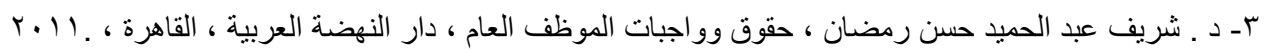

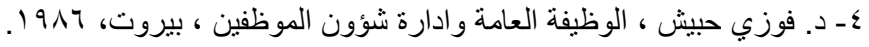

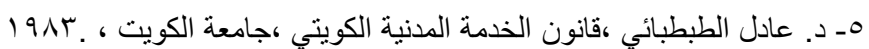

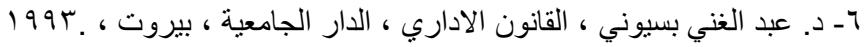

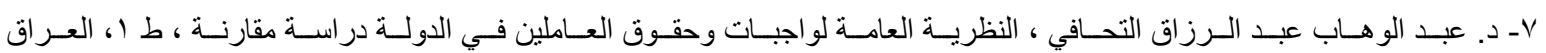
بغداد.

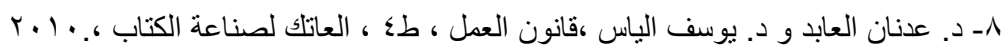




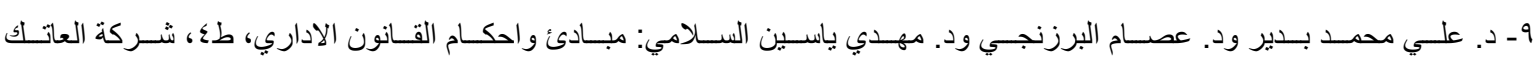

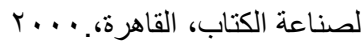

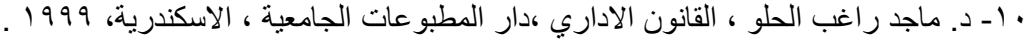

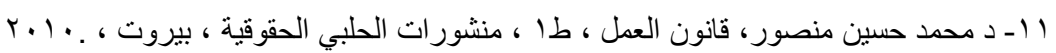

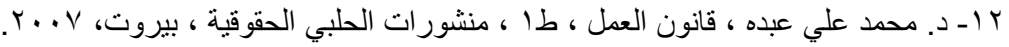
ب- النشرات القضائية

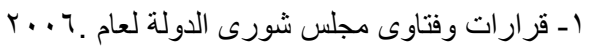

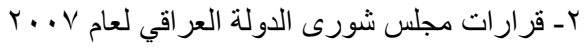

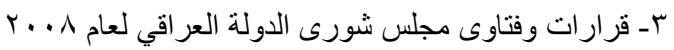

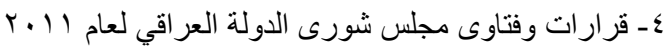
ج- التشريعات

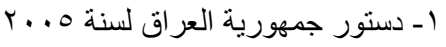

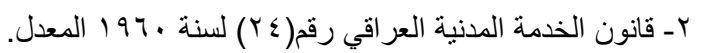

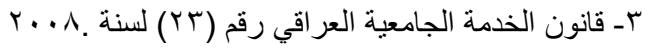

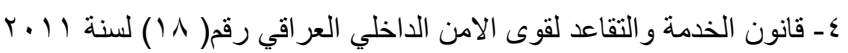

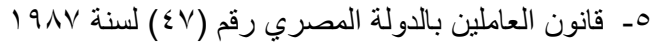

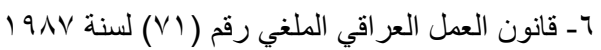

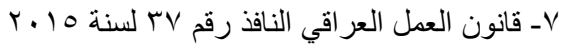

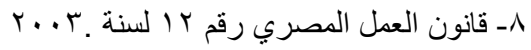

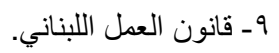

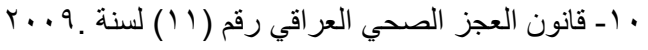

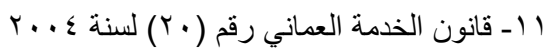

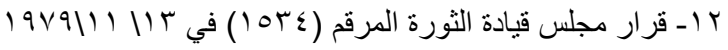

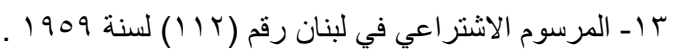

